\title{
LIGHT-ACTIVATED GENE EXPRESSION
}

\author{
by \\ Federico Guillermo Cruz
}

A thesis submitted to the Faculty of the University of Delaware in partial fulfillment of the requirements for the degree of Doctor of Philosophy in Chemistry and Biochemistry

Fall 2016

(C) 2016 Federico Guillermo Cruz

All Rights Reserved 
ProQuest Number: 10244978

All rights reserved

INFORMATION TO ALL USERS

The quality of this reproduction is dependent upon the quality of the copy submitted.

In the unlikely event that the author did not send a complete manuscript and there are missing pages, these will be noted. Also, if material had to be removed, a note will indicate the deletion.

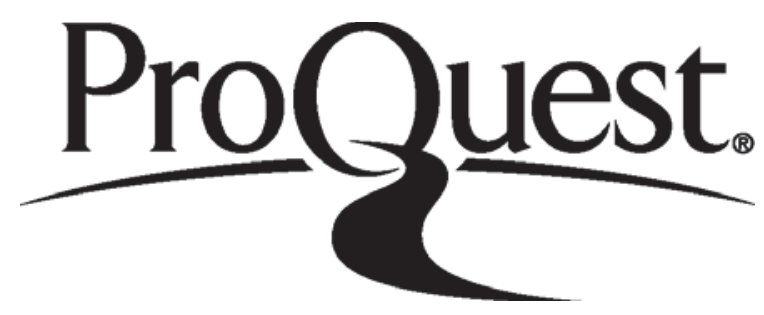

ProQuest 10244978

Published by ProQuest LLC (2017). Copyright of the Dissertation is held by the Author.

All rights reserved.

This work is protected against unauthorized copying under Title 17, United States Code Microform Edition (C) ProQuest LLC.

ProQuest LLC.

789 East Eisenhower Parkway

P.O. Box 1346

Ann Arbor, Ml $48106-1346$ 


\title{
LIGHT-ACTIVATED GENE EXPRESSION
}

\author{
by
}

\author{
Federico Guillermo Cruz
}

Approved:

Murray V. Johnston, Ph.D.

Chair of the Department of Chemistry and Biochemistry

Approved:

George H.Watson, Ph.D.

Dean of the College of Arts and Sciences

Approved:

Ann L. Ardis, Ph.D.

Senior Vice Provost for Graduate and Professional Education 
I certify that I have read this dissertation and that in my opinion it meets the academic and professional standard required by the University as a dissertation for the degree of Doctor of Philosophy.

Signed:

John T. Koh, Ph.D.

Professor in charge of dissertation

I certify that I have read this dissertation and that in my opinion it meets the academic and professional standard required by the University as a dissertation for the degree of Doctor of Philosophy.

Signed:

Joseph M. Fox, Ph.D.

Member of dissertation committee

I certify that I have read this dissertation and that in my opinion it meets the academic and professional standard required by the University as a dissertation for the degree ofDoctor of Philosophy.

Signed:

Colin Thorpe, Ph.D.

Member of dissertation committee

I certify that I have read this dissertation and that in my opinion it meets the academic and professional standard required by the University as a dissertation for the degree of Doctor of Philosophy.

Signed:

Erin Bernberg, Ph.D.

Member of dissertation committee 


\section{ACKNOWLEDGMENTS}

I will like to thank all the people who have support me during my time in the Chemistry and Biochemistry department. I will specially like to thank my friend and mentor Professor John T. Koh for not giving up on me during my difficult times. In addition, I would also like to thank the faculty who have support me during my time in the department especially Professor Brown, Professor Munson, and Professor Thorpe. I will also like to thank my dissertation committee for taking time to help me achieve this goal: Professor Koh, Professor Fox, Professor Thorpe, and Dr. Bernberg. I would also like to acknowledge all of the staff members, past and present that supported and helped me during my time in the department. I would like to thank all of the undergraduate and graduate students during my time at the University, who kept things interesting when I interacted with them. Finally, I would like to thank my family for their patience, love and support. 


\section{TABLE OF CONTENTS}

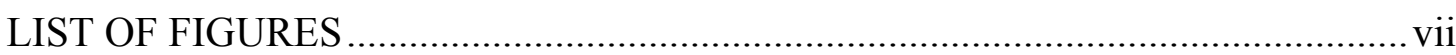

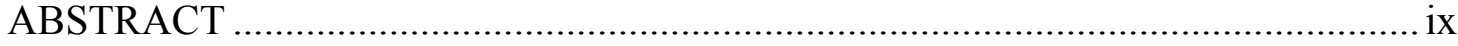

Chapter

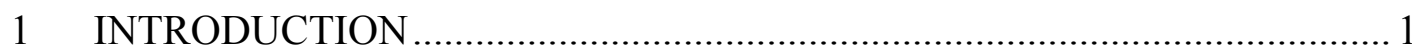

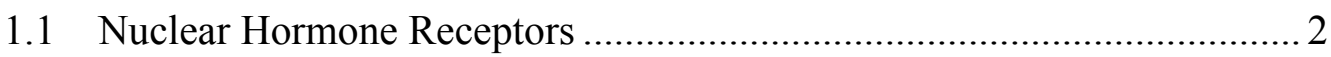

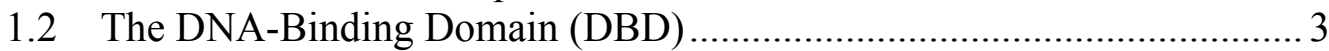

1.3 The Ligand-Binding Domain (LBD).................................................... 4

1.4 The Mechanism of Hormone Action ....................................................... 5

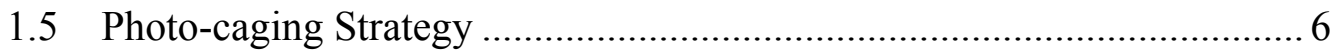

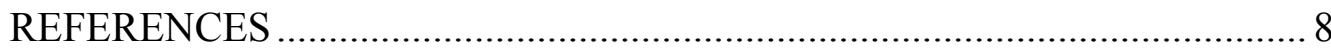

2 ESTROGEN RECEPTOR AND THE FIRST LIGHT-ACTIVATED

TRANSCRIPTIONAL SYSTEM ............................................................. 10

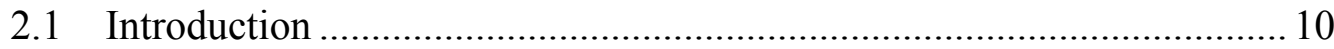

2.2 Mechanism of ER Action ...................................................................... 11

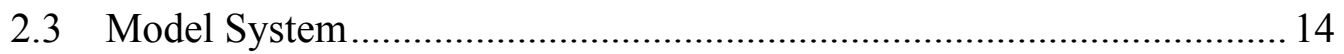

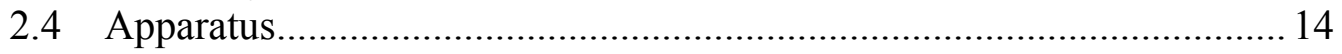

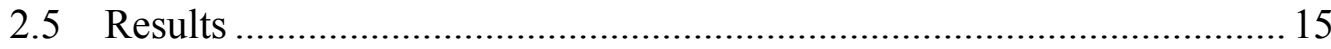

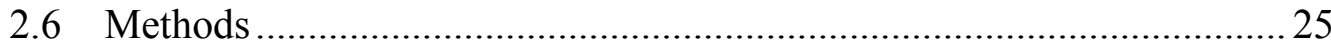

2.6.1 Transient Transfection Assays (General Procedure) ……............25

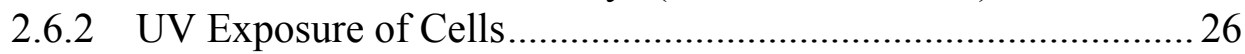

2.6.3 Exposure Dependence of Gene Product Formation .....................26

2.6.4 Determination of Intracellular De-protection by Prewashing .....27

2.6.5 Evaluating Compound Stability by Incubating in Cell Lysates ..27

2.6.6 Antagonists Properties Assessed by Using Estradiol ...................28

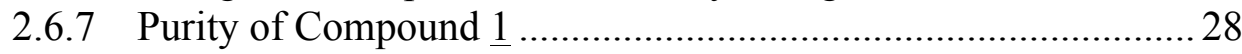

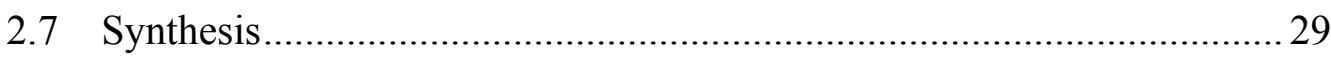

2.7.1 Preparation of 4,5-Dimethoxy-2-nitrobenzyl-estradiol (1) ….....29

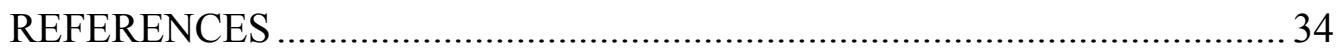


3 PHOTO-CAGED AGONISTS OF THE NUCLEAR RECEPTORS: RETINOID ACID (RAR) AND THYROID (TR) ........................................ 36

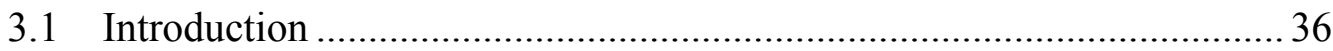

3.2 Photo-stable Agonists of Retinoid and Thyroid Receptors .................... 37

3.3 Photo-caged Agonists Efficiently Release Photo-stable Agonists in

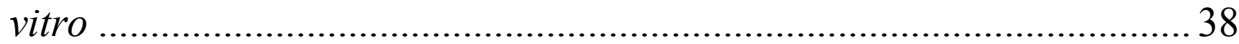

3.4 Photo-caged Ligands are Stable under Cellular Conditions.................... 40

3.5 Photo-caged Ligands Do Not Act as Agonists or Antagonists with

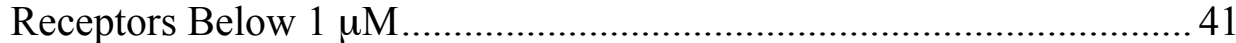

3.6 Caged Ligands Can Mediate Exposure Dependent RAR and TR Dependent Transactivation Response ................................................... 44

3.7 Intracellular Uncaging Provides a Transient Transactivation Response. 46

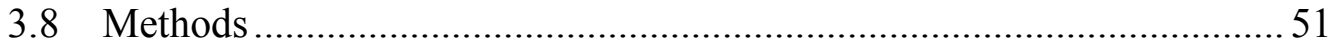

3.8.1 Transient Transfection Assays ................................................... 51

3.8.2 Cell Exposure Procedure ...................................................... 52

3.8.3 Intracellular De-protection by Prewashing............................... 52

3.8.4 Evaluation of Compound Stability to Cell Lysates .................... 53

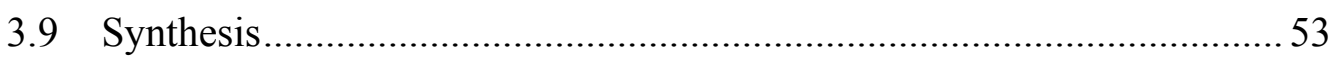

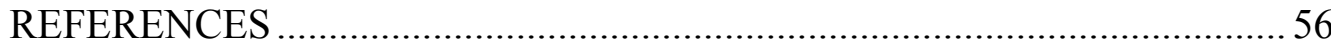

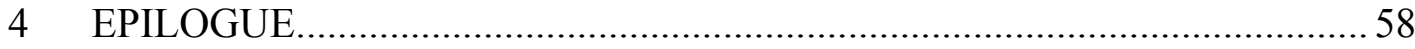

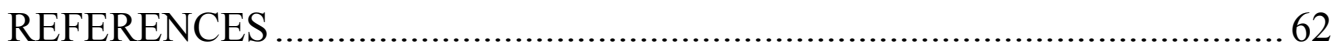

Appendix

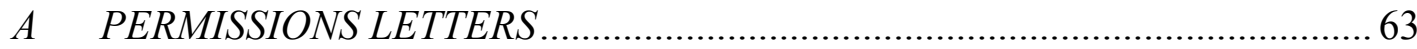




\section{LIST OF FIGURES}

Figure 1.1: Mechanism of action of the Nuclear Hormone Receptors........................... 6

Figure 2.1: Mechanism of ER action. HSP90: Heat Shock Protein; CA = transcriptional co-activator ..................................................................... 11

Figure 2.2: Interactions of E2 with Arg394 \& Glu353............................................. 12

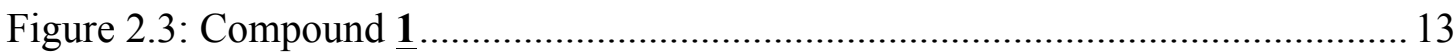

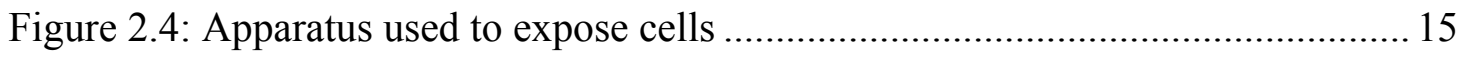

Figure 2.5: Rate of caged compound $\underline{1}$ disappearance and product formation upon

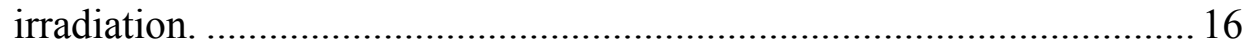

Figure 2.6: Compound $\underline{1}$ weakly suppresses luciferase transactivation response in HEK293 cells. .................................................................................... 18

Figure 2.7: Cellular reporter gene (luciferase) activity measured 24 hours after a 3 minutes exposure in HEK293 cells.

Figure 2.8: Exposure dependence of transactivation response of luciferase reporter

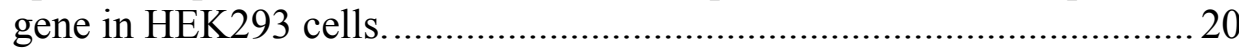

Figure 2.9: Time dependence of gene product formation after photo-release of estradiol. ...................................................................................... 21

Figure 2.10: Time dependence of gene product formation after exposure. Cells incubated in $10 \mathrm{nM} 1$ or E2 are washed prior to a 12 minute UV

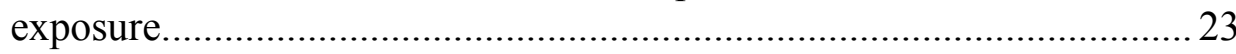

Figure 2.11: HPLC analysis of $\underline{1}$ shows no visible contamination from estradiol.......29

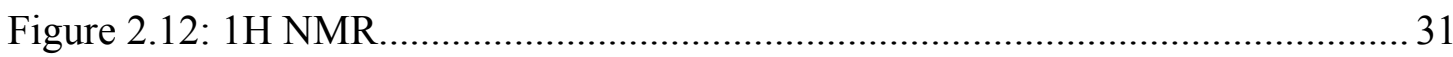

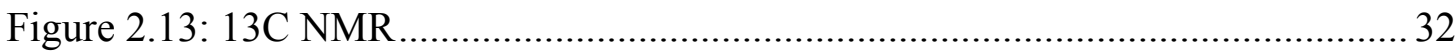

Figure 2.14: Comparison of alkylation at the 1-hydroxyl position between estradiol and compound $\underline{1}$. 
Figure 3.1: Light-stable agonists and photo-caged analogs 37

Figure 3.2: Synthesis of caged agonists $\underline{\mathbf{3}}$ in scheme (A) and $\underline{\mathbf{4}}$ in scheme (B) 38

Figure 3.3: Exposure dependence of photodeprotection and product formation. Compounds $\underline{\mathbf{3}}(\mathbf{O})$ and $\underline{\mathbf{4}}(\boldsymbol{\square})$ are converted to agonists $\underline{\mathbf{1}}(\mathrm{O})$ and $\underline{\mathbf{2}}$ (口).

Figure 3.4: Treatment of photocaged ligands ( $\underline{3} \& \underline{\mathbf{4}})$ with cell lysates does not effect transactivation function in unexposed cells. (A) HeLa cells transfected with RAR reporter gene and incubate with compound $\underline{\mathbf{3}}$. (B) HeLa cells transfected with the TR reporter and incubate with compound 4. White bars are unexposed cells and black bars are exposed cells.

Figure 3.5: Photocaged compounds $\underline{\mathbf{3}}$ and $\underline{\mathbf{4}}$ show very little transcriptional activity below $1000 \mathrm{nM}$ in cells expressing (A) RAR or (B) TR.

Figure 3.6: Compounds $\underline{3} \& \underline{4}$ do not antagonize RAR or TR dependent transactivation. (A) Cells expressing RAR treated with $800 \mathrm{nM}$ of 1 and increasing concentrations of $\underline{\mathbf{3}}$ and $(\mathrm{B})$ cells expressing TR treated with $100 \mathrm{nM}$ of $\underline{\mathbf{2}}$ and increasing concentrations of $\underline{4}$.

Figure 3.7: Gene expression activity determined 24 hours after exposure. (A) Cells expressing RAR reporter gene with $800 \mathrm{nM}$ of $\underline{\mathbf{3}}$ (b) or no ligand added (c). (B) Cells expressing TR reporter gene with $500 \mathrm{nM}$ of $\underline{4}$ (b) or no ligand added (c). Dark diamonds are exposed cells and white squares are unexposed cells.....

Figure 3.8: Fluorescence micrograph of HeLa cells incubated with compound $\underline{\mathbf{1}}$ and observed under upright microscope with dipping lens.

Figure 3.9: Time dependence of luciferase formation after a 90 second exposure. (A) Cells expressing RAR reporter gene with $800 \mathrm{nM}$ of $\underline{\mathbf{3}}$. (B) Cells expressing the TR reporter gene with $500 \mathrm{nM}$ of $\underline{4}$. Solid: ligand uncaged in media and cells; Dash: ligand uncaged in cells only after prewashing; Circle: not irradiated.

Figure 3.10: The formation of protein product is represented as an intermediate between transcription/translation and protein degradation. The duration of transactivation response is limited by the decomposition of the receptor-associated transcription complex. 


\begin{abstract}
A method for activating gene expression in cells by using photo-caged small molecules was developed. This method uses the Nuclear Hormone Receptor (NHR) family as a model system. This tool provided an opportunity to study the spatial and temporal control of genes by using small synthetic molecules and light. In the late 1990s, we first demonstrated this concept by using as a photo-caged $\beta$-estradiol, the hormone for the estrogen receptor (ER). This work opened the door to other lightcontrolled ligand/receptor systems by the Koh group and others. The majority of examples employ a classical caging technology, by chemically adding a lightremovable protecting group on a biological small molecule of interest and rendering it inactive. The caging group is removed upon UV light irradiation leading to activation of the molecule. The approach and methods developed herein during the late 1990s is still being used today.
\end{abstract}




\section{Chapter 1}

\section{INTRODUCTION}

Advances have been made in the activation and suppression of gene expression using light. The developments are based on the application of small molecule inducers of gene expression and the photochemical control of proteins that regulate gene

function. ${ }^{1}$ At the start of this work, the majority of the systems employ a classical 'caging technology' through the chemical introduction of a light-removable protecting group on a biological macromolecule such as oligonucleotide or proteins. ${ }^{2-3}$

Exposing these molecules to UV irradiation removes the caging group and activates the molecule of interest that can then turn on gene expression with high spatial and temporal resolution. Early applications of these techniques were limited by the challenges of introducing macromolecules into cells and/or cells within an organism. Additionally, systems using photocaged macromolecules were not very light-sensitive and investigation of the system by standard light microscopy methods could result in unintended activation of additional caged molecules.

In this work we look at one of the first systems to control gene transcription through the actions of light using photocaged small molecules as transcriptional mediators. Systems that are controlled by small molecules have many distinct advantages. 
Compared to macromoleucles, small molecule effectors can more readily cross the cell membrane and are more likely to show favorable in vivo bioavailability. Membrane permeability also means the ligand can be washed in or washed out of the cell rendering the cell only transiently light-sensitive. This is of particular importance as many light microscopy methods tend to cause unwanted uncaging events when attempting to observe the effects of uncaging. The ability to make systems transiently light sensitive to one ligand by ligand wash-in/wash-out means that in principle, multiple caged ligands can be independently patterned within the same tissue using the same caging groups.

\subsection{Nuclear Hormone Receptors}

This work will focus on the first examples of light-activated gene expression that used nuclear/steroid hormone receptors as ligand-dependent transcription factors. Therefore the following section will summarize key features of NHRs relevant to their applications as mediators of light-activated transcription.

The nuclear hormone receptor gene superfamily also known as the steroid/thyroid hormone receptor gene superfamily encodes structurally related intracellular receptors for glucocorticoids, androgens, mineralcorticoids, progestins, estrogens, thyroid hormones, vitamin D, retinoic acid, and 9-cis retinoic acid. ${ }^{4-6}$

The nuclear hormone receptor superfamily is organized into a set of functional domains which include an N-terminal A/B domain with varied function, a DNA 
binding domain ${ }^{7}$, a hinge region, a ligand binding domain ${ }^{8}$, which includes the liganddependent transactivation function. Some receptors have, in addition, an C-terminal Fdomain.

\subsection{The DNA-Binding Domain (DBD)}

The DNA-binding domain is a highly conserved and has a greater than $40 \%$ homology between receptors. Its function is for DNA binding and dimerization as nuclear hormone receptors can associate as homodimers or heterodimers. The DBD is responsible for targeting receptors to their corresponding hormone response elements. The amino-terminal domain is hyper-variable and functions in transactivation. In addition, the DNA binding domain forms homodimeric or heterodimeric complexes on specific DNA sequences found in the promoter region of hormone responsive genes known has hormone response elements or HREs. The DBDs of NHRs have been studied extensively and are composed of a distinct protein fold composed of two zinc fingers. Variations in the dimerization interfaces (known as p-box and d-box regions) provide specificity to HRE that are nominally composed of a pair of half sites made from one of two canonical half-site sequences arranged as directs repeats, palindromic repeats or inverted repeats. Significantly the DNA binding domain and the ligand binding domains function largely independent of one another, allowing construction of chimeric receptors that can have altered or even unique promoter specificities $^{19}$. 


\subsection{The Ligand-Binding Domain (LBD)}

The ligand binding domain has a unique alpha-helical sandwich structure that can selectively bind its cognate hormone to undergo a conformational change involving the repositioning of helix-12, which results in the formation of a binding surface for coactivators. This AF-2 (activation function-2) domain binds to a LXXLL helical peptide sequence called receptor interaction domains (RID) that are part of coactivator proteins ${ }^{20}$.

The LBD also participates in homo- and hetero-dimerization of NHRs. They also mediate binding to heat shock proteins that both stabilizes the protein in the absence of ligand, and affects cytoplasmic localization. In its bound state, hormones are completely encapsulated within the LBD. Modifications that extend the size of the ligand can easily result in the hormone analog being unable to bind the receptor while other such extensions have been found to block conformational switching and thus act as antagonist. For the studies described herein, we will primarily be interested in modifications that can be removed by light that prevent the modified ligand from binding.

The large conformational reorganization of the receptor also affects the kinetics of binding. Ligand off-rates are strongly influenced by the presence of coactivators, which can extend the half time $\left(t_{1 / 2}\right)$ for dissociation from several minutes to a few hours ${ }^{21}$. As we will see in later chapters this slow off rate will allow us to control transcription response for extended periods. 


\subsection{The Mechanism of Hormone Action}

The figure below shows the general mechanism of action ${ }^{9}$ for the nuclear hormone receptors. The ligands enter the cell through different pathways. For example, steroids and vitamin D enter cells through passive diffusion. In contrast, thyroid hormone and retinoic acid may involve specific transport processes. The ligands encounter the receptors in various forms. Unliganded steroid receptors are bound in a complex with heat-shock proteins, including HSP90, HSP70, and several others. Most receptor-HSP complexes are present in the cytoplasm, although estrogen receptor complexes are present in the nucleus. Hormone binding dissociates the receptors from these complexes, and the liganded receptors form homodimers that bind to hormone response elements (HRE) in the promoter region of the target genes. In addition, nuclear hormone receptors can bind to simple response elements with nonreceptor proteins that affect the receptor action to composite elements. 


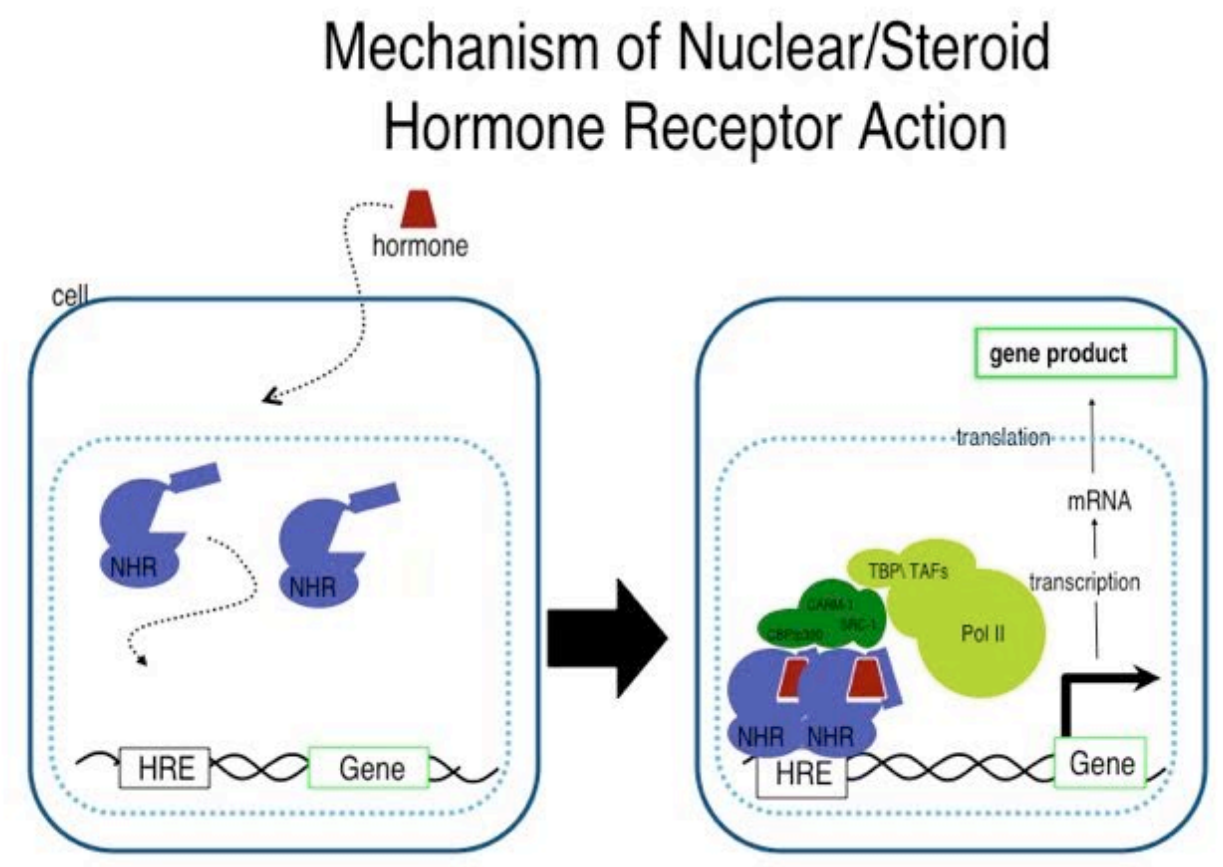

Figure 1.1: Mechanism of action of the Nuclear Hormone Receptors.

\subsection{Photo-caging Strategy}

The use of photo-caging technologies has become a standard approach to temporarily render inactive a biologically active small molecule or macromolecule through the use of a light-sensitive protecting group (caging group). ${ }^{10-11}$ By exposing these molecules to non-damaging UV light the caged molecule is released in its active biological form. This caging technology provides precise spatial and temporal control over biological processes that can be used to produce a rapid activation of cellular processes. The most common protecting group used is the 2-nitrobenzyl group ${ }^{12}$ on an oxygen, nitrogen or sulfur atom that inactivates the biologically active molecule. Upon 
exposure to UV light the caged molecule is deprotected, leading to the restoration of the activity of the biological molecule.

Several methods have been established to control the mechanisms of gene function that rely on small molecule inducers of gene expression. The use of a small molecule or protein to activate or inhibit gene transcription has become a valuable tool in the regulation of genes. After my pioneering studies on photocaged estrogen ${ }^{13}$ and the estrogen receptor, several examples of caged small molecules to control gene expression have been described in the literature by the Koh $1 a b^{14-15}$ and others. These include caged version of ecdysone ${ }^{16}$, isopropyl- $\beta$-D-thiogalactopyranoside ${ }^{17}$, and tamoxifen ${ }^{18}$. My work's impact on the field as one of the early systems for lightactivated gene expression opened the door to new methods to control gene expression with high temporal and spatial resolution. 


\section{REFERENCES}

1. Allgood, V.; Eastman, E.; Bristol, J., Novel gene switches for the regulation of gene expression. Annual Reports in Medicinal Chemistry, Vol 32 1997, 32, 231-239.

2. Curley, K.; Lawrence, D., Caged regulators of signaling pathways. Pharmacology \& Therapeutics 1999, 82 (2-3), 347-354.

3. Curley, K.; Lawrence, D., Light-activated proteins. Current Opinion in Chemical Biology 1999, 3 (1), 84-88.

4. Katzenellenbogen, J.; Katzenellenbogen, B., Nuclear hormone receptors: Ligandactivated regulators of transcription and diverse cell responses. Chemistry \& Biology 1996, 3 (7), 529-536.

5. Aranda, A.; Pascual, A., Nuclear hormone receptors and gene expression. Physiological Reviews 2001, 81 (3), 1269-1304.

6. Robinson-Rechavi, M.; Garcia, H.; Laudet, V., The nuclear receptor superfamily. Journal of Cell Science 2003, 116 (4), 585-586.

7. Helsen, C.; Kerkhofs, S.; Clinckemalie, L.; Spans, L.; Laurent, M.; Boonen, S.; Vanderschueren, D.; Claessens, F., Structural basis for nuclear hormone receptor DNA binding. Molecular and Cellular Endocrinology 2012, 348 (2), 411-417.

8. Moras, D.; Gronemeyer, H., The nuclear receptor ligand-binding domain: structure and function. Current Opinion in Cell Biology 1998, 10 (3), 384-391.

9. Gronemeyer, H.; Gustafsson, J.; Laudet, V., Principles for modulation of the nuclear receptor superfamily. Nature Reviews Drug Discovery 2004, 3 (11), 950-964.

10. Ellis-Davies, G., Caged compounds: photorelease technology for control of cellular chemistry and physiology. Nature Methods 2007, 4 (8), 619-628.

11. Yu, H.; Li, J.; Wu, D.; Qiu, Z.; Zhang, Y., Chemistry and biological applications of photo-labile organic molecules. Chemical Society Reviews 2010, 39 (2), 464-473.

12. Klan, P.; Solomek, T.; Bochet, C.; Blanc, A.; Givens, R.; Rubina, M.; Popik, V.; Kostikov, A.; Wirz, J., Photoremovable Protecting Groups in Chemistry and Biology: Reaction Mechanisms and Efficacy. Chemical Reviews 2013, 113 (1), 119-191. 
13. Cruz, F.; Koh, J.; Link, K., Light-activated gene expression. Journal of the American Chemical Society 2000, 122 (36), 8777-8778.

14. Biggins, J.; Hashimoto, A.; Koh, J., Photocaged agonist for an analogue-specific form of the vitamin D receptor. Chembiochem 2007, 8 (7), 799-803.

15. Shi, Y.; Koh, J., Light-activated transcription and repression by using photocaged SERMs. Chembiochem 2004, 5 (6), 788-796.

16. Lin, W.; Albanese, C.; Pestell, R.; Lawrence, D., Spatially discrete, light-driven protein expression. Chemistry \& Biology 2002, 9 (12), 1347-1353.

17. Lee, J.; Lee, J.; Kim, T.; Lee, S., Switchable Gene Expression in Escherichia coli Using a Miniaturized Photobioreactor. Plos One 2013, 8 (1).

18. Link, K.; Shi, Y.; Koh, J., Light activated recombination. Journal of the American Chemical Society 2005, 127 (38), 13088-13089.

19. Danielsen, M.; Martinez, E.; Nagarajan, P., Analysis of the hormone-binding domain of steroid receptors using chimeras generated by homologous recombination. Experimental Cell Research 2005, 308 (2), 320-333.

20. Chen, J.; Leo, C., The SRC family of nuclear receptor activators. Gene 2000, 245 (1), 1-11.

21. Greene, G.; Nettles, K., Ligand control of coregulator recruitment to nuclear receptors. Annual Review of Physiology 2005, 67, 309-333. 


\section{Chapter 2}

\section{ESTROGEN RECEPTOR AND THE FIRST LIGHT-ACTIVATED TRANSCRIPTIONAL SYSTEM}

\subsection{Introduction}

Estrogen receptors (ER) are a group of proteins located inside and on the surface of cells. ${ }^{1-2}$ ERs can exist in two forms: nuclear estrogen receptors and membrane associated estrogen receptors. Once the estrogen receptor is activated by estrogen, it is able to translocate into the nucleus and bind DNA to regulate the activity of different genes. As one of the hormone receptors for the sex steroids, it is important for sexual maturation and gestation.

There are two different subtypes of the estrogen receptor that are referred to as the alpha and beta forms that are encoded by separate genes. ERs form homo or hetero dimers. The estrogen receptor alpha and beta show a significant sequence homology and are composed of five domains.

Estrogen induces cellular changes through different mechanisms. The classical mechanism of estrogen action is when estrogen diffuses into the cell and bind to the estrogen receptor, which then translocates into the nucleus. The ER complex binds to estrogen response elements that recruit co-regulatory proteins to the promoter to induce transcriptional response to downstream genes as shown in Figure 2.1. This mechanism usually occurs over the course of hours. In addition, estrogen can act more 
quickly through a different mechanism that involves non-ER plasma membrane binding proteins.

\subsection{Mechanism of ER Action}

The three-dimensional crystal structures of the independently-expressed $\mathrm{DBD}^{3-}$ 5 and $\mathrm{LBD}^{6}$ have been solved for the estrogen receptors.

The crystal structure of the human ER beta bound to estradiol is known and can be use to develop our caged ligands. Therefore, we decided to use the estrogen receptor as a model system to develop the concept of light activated gene expression by small molecules.

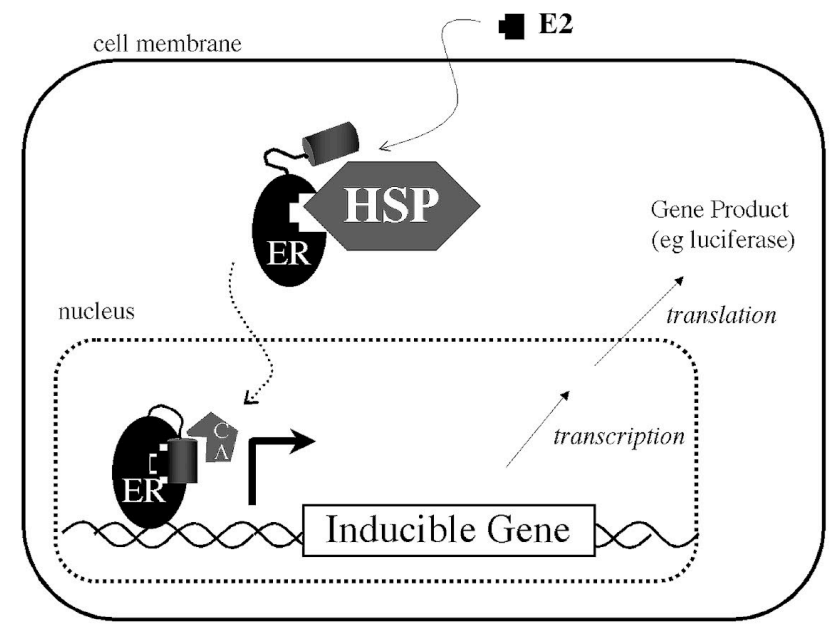

Figure 2.1: Mechanism of ER action. HSP90: Heat Shock Protein; $\mathrm{CA}=$ transcriptional co-activator 

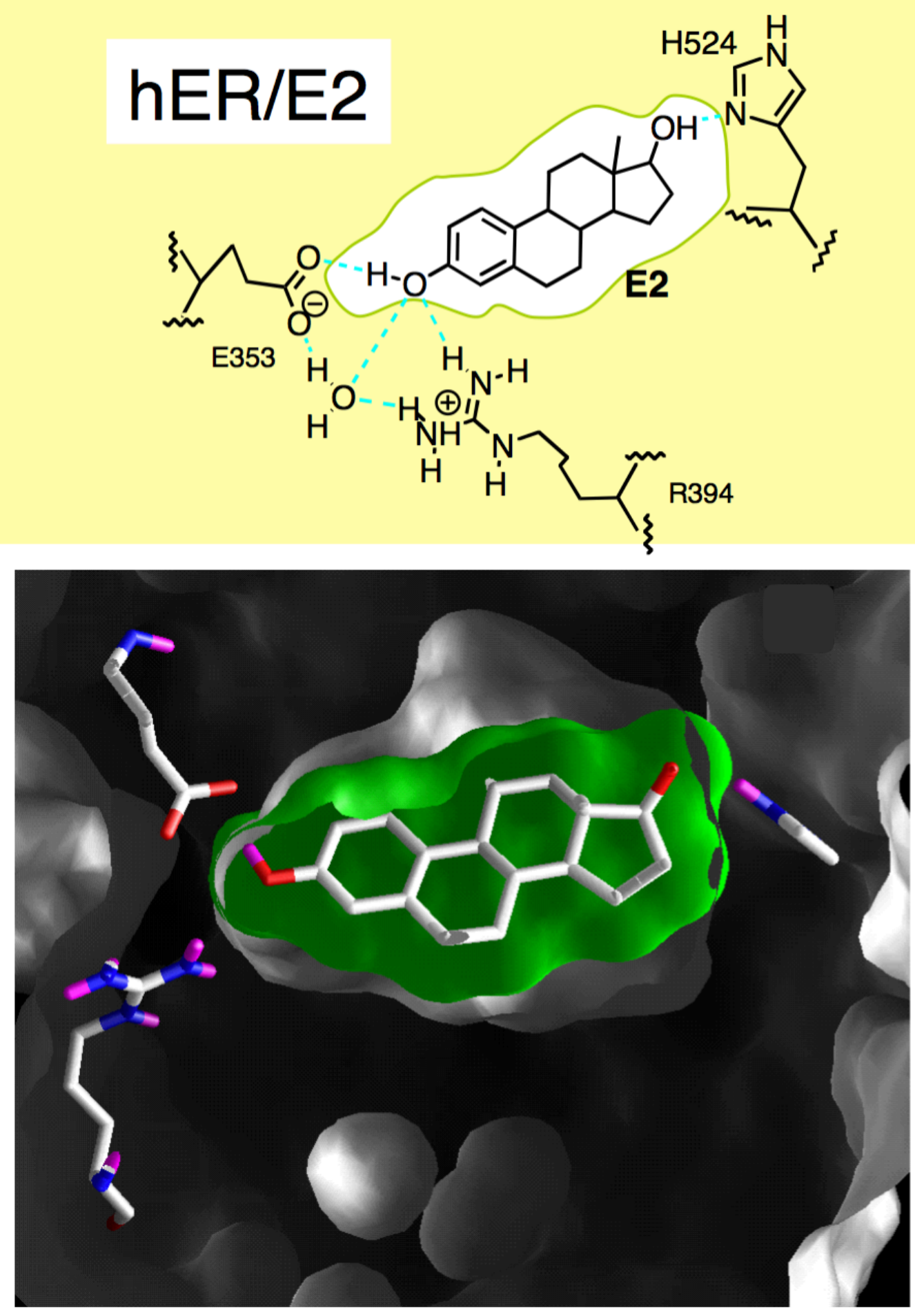

Figure 2.2: Interactions of E2 with Arg394 \& Glu353. 
From both the crystal structure and mutagenesis studies, the interactions of the 1-hydroxyl group of estradiol (E2) with Arg394 and Glu353 have been shown to be critical for ligand binding as shown in Figure 2.2. ${ }^{4,5,7}$ Therefore, compound $\mathbf{1}$, a photocaged analogue of estradiol was predicted to be a non-ligand to the estrogen receptor (Figure 2.3). However, molecule 1 can be rapidly reverted to estradiol upon exposure to UV light. Therefore, this compound may be useful for mediating light-activated gene expression. For synthesis of compound $\underline{\mathbf{1}}$, go to section 2.7.1.

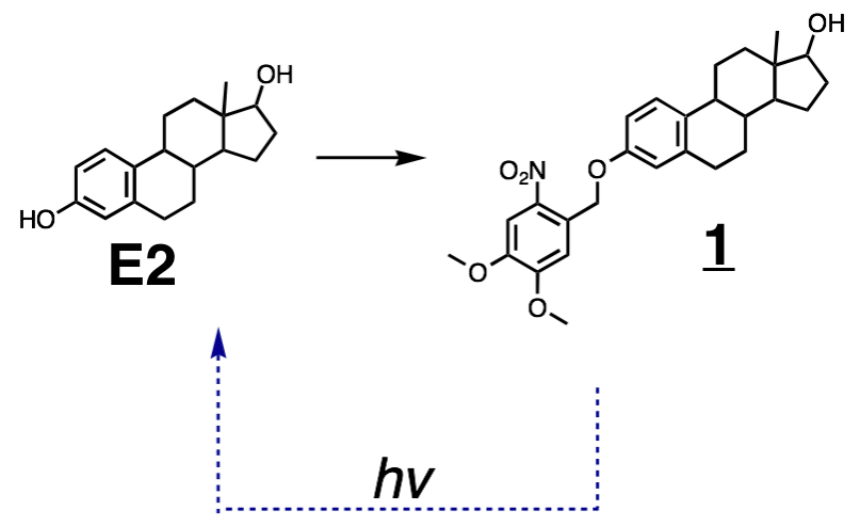

Figure 2.3: Compound 1

In this project, compound 1 was evaluated for its ability to induce luciferase reporter gene expression in HEK293 cells transiently transfected with ER expression 
plasmid pSG1-HEO ${ }^{8}$, the luciferase reporter ERE-luc and control plasmid pRLCMV from Promega. The cells were grown in standard culture wells that were irradiated with UV light. To avoid excessive heating and UV damage from the UV light, infrared and short wavelength UV light, a new protocol needed to be developed.

\subsection{Model System}

Once we decided to use the estrogen receptor as our model; we needed a procedure to light activate cells that have our caged ligand. Our first attempt consisted of using a mercury arc lamp to deprotect the synthetic ligand that was present in culture media. In free solution, the deprotection of the caged ligand worked well, but in the presence of cells, the mercury arc-lamp irradiation lead to considerable UV damage of the cells. Significantly, at lower exposures than needed to cause obvious cell toxicity, UV irradiation and heat from the lamp induced considerable activation of our reporter gene in the absence of caged or uncaged ligand, presumably through the activation of heat-shock response pathways.

\subsection{Apparatus}

Our future attempts to irradiate live cells were done using a standard long-wave (UV-A) fluorescent UV lamp. In the beginning, this also led to toxic or heat-shock response but through several trials we found a experimental setup where we could use the UV lamp for the deprotection of the caged ligand without detectable background 
cellular response. This method involved using a spacer to place the fluorescent UV lamp above the sample and filtering the IR and UV light through a glass plate that acts as a filter to absorb IR light and the polystyrene lid of the culture well plate which absorbs short-wavelength UV (See Figure 2.4). Our experimental design has since been used by other groups to activate synthetic ligands inside cells.

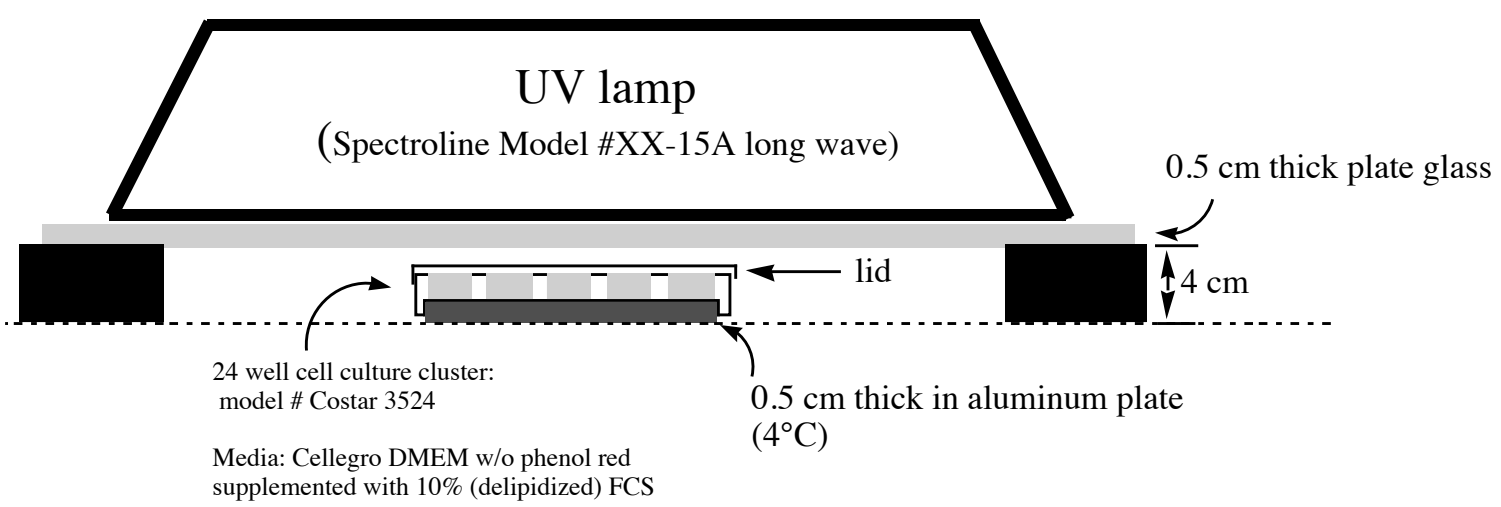

Figure 2.4: Apparatus used to expose cells

\subsection{Results}

As even UV-A irradiation can cause cellular damage, the uncaging efficiency is an important design consideration of this project. The quantum yield is defined as the number of times a specific event occurs per photon absorbed by the system through a radiation-induced process. Though the quantum yield is important, equally important 
is the chemical yield that measures the effectiveness of a chemical process to produce the desired product. Using our irradiation apparatus, we monitored the deprotection of $\underline{\mathbf{1}}$ in methanolic solutions in tissue culture wells by HPLC. For compound $\underline{\mathbf{1}}$ irradiation causes rapid disappearance of the starting materials but with only approximately $40 \%$ of $\underline{1}$ being converted to free E2 (Figure 2.5). For our purposes this is sufficient and a lower chemical yield can be compensated for by adding more caged compound 1 .

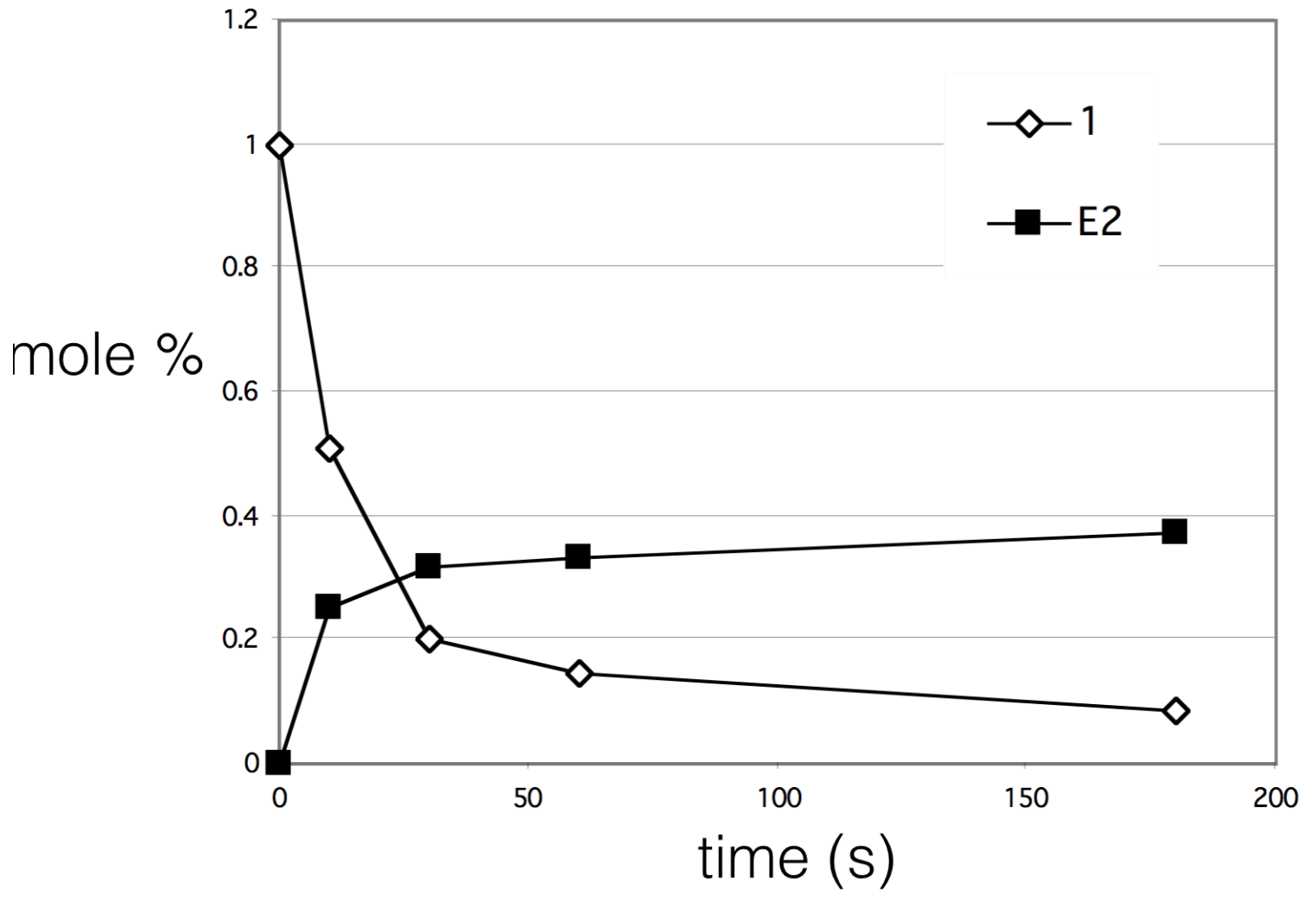

Figure 2.5: Rate of caged compound 1 disappearance and product formation upon irradiation. 
Throughout this project we learned that the deprotection behavior of photocaged compounds is not the same for all compounds even when using the same protecting group. In addition, one must be cognizant that photo-caged compounds are never $100 \%$ caged. Photo-caged compounds often have some residual (i.e. weak agonist) activity and compounds invariably contain some small amount of the unprotected form. Therefore we need to find out how much of the caged molecule can be placed inside the cell media without causing an increased background signal. Additionally, when working with receptors such as nuclear hormone receptors, it is useful to evaluate if the caged compounds act as antagonists that could suppress the activity of the uncaged agonist. Therefore, HEK293 cells expressing ER and an ER responsive luciferase reporter were treated with E2 and increasing concentrations of $\underline{1}$. At high concentrations $\left(\mathrm{IC}_{50}>600 \mathrm{nM}\right)$ the caged compound acts as a weak antagonist of ER. Significantly, the concentrations of $\underline{1}$ required for our studies, 5 to $10 \mathrm{nM}$, are considerably below the levels that cause any significant changes to ER activity (Figure 2.6). 


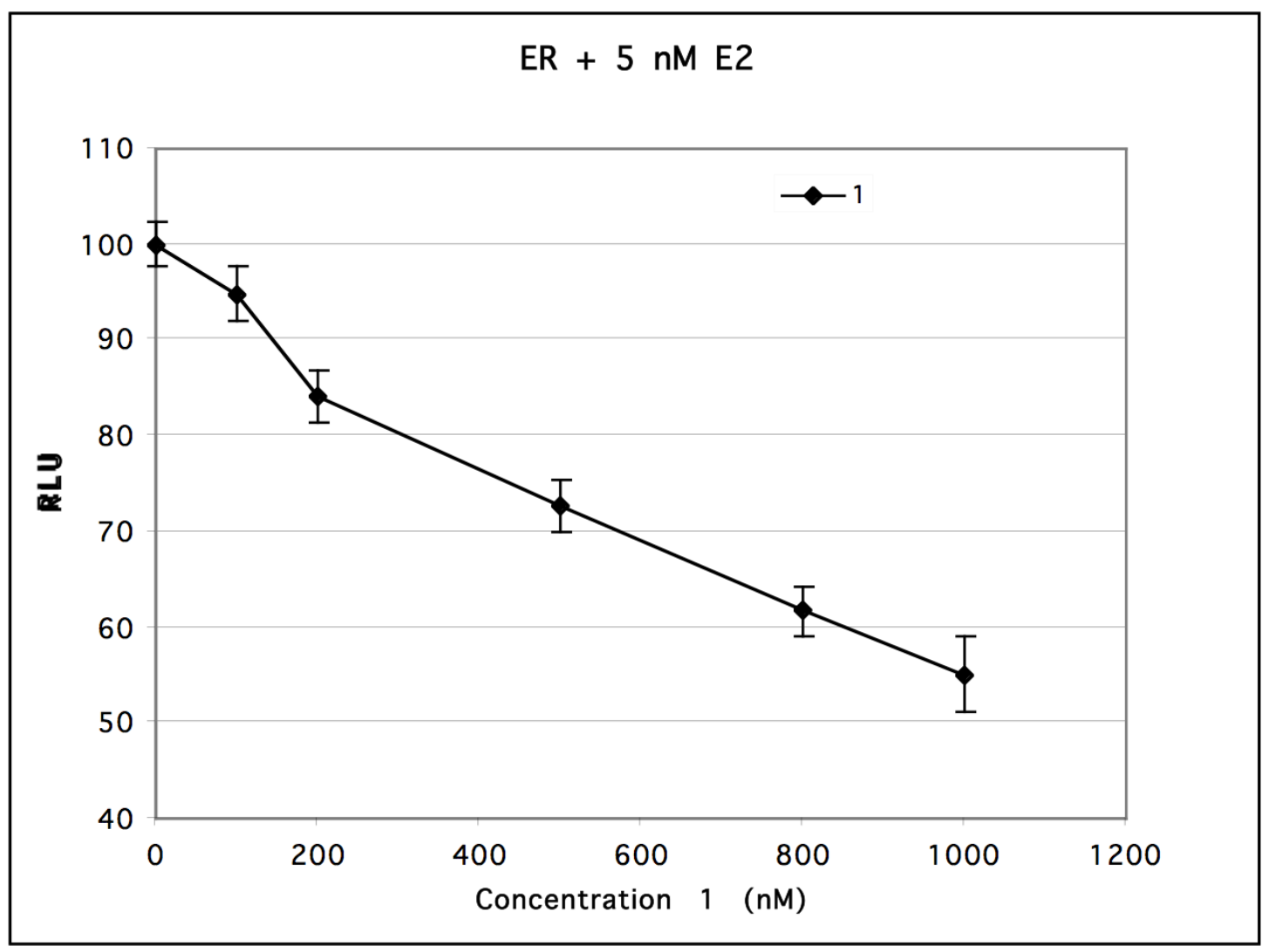

Figure 2.6: Compound 1 weakly suppresses luciferase transactivation response in HEK293 cells.

Light-activated gene expression was demonstrated by treating HEK293 cells transiently transfected with pSG5-HEO, ERE-luc and pRL(basic) (renilla control) with $5 \mathrm{nM}$ 1. After $12 \mathrm{~h}$, cells were either irradiated with UV-A light for 3 minutes or kept in the dark. Control cells, not treated with $\underline{1}$ were similarly irradiated. After $24 \mathrm{~h}$ incubation, cells were lysed and luciferase activity was determined by dual luciferase assay ${ }^{9}$. Transcription response was determined as RLU (relative light units) 
determined by dividing the firefly luciferase activity by the renilla luciferase activity. Cells treated with just $5 \mathrm{nM} 1$ and irradiated achieved $86 \%$ of full ligand inducible response whereas identical cells kept in the dark showed a negligible transcription response. Significantly, control cells that were not treated with $\underline{\mathbf{1}}$, did not show a significant increase in transcription upon identical irradiation conditions. This allows the rapid introduction of active ligands into cells that can trigger hormone receptormediated transcription/translation (Figure 2.7).

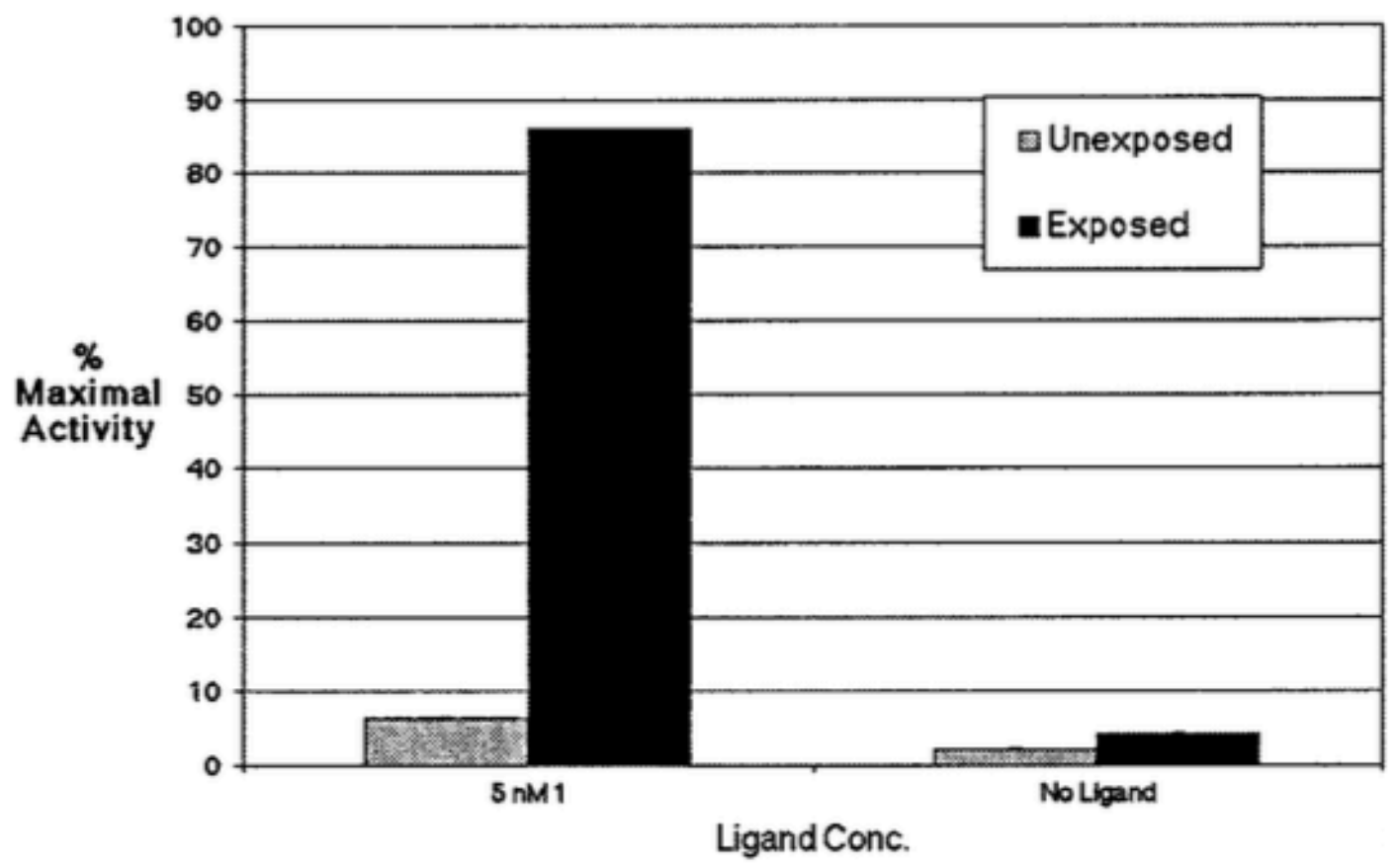

Figure 2.7: Cellular reporter gene (luciferase) activity measured 24 hours after a 3 minutes exposure in HEK293 cells. 
The stability of compound $\underline{\mathbf{1}}$ in culture is also important for independent regulation of genes. Pretreatment of $\underline{\mathbf{1}}$ with cell lysates affords no additional activity in cell culture suggesting that compound $\underline{\mathbf{1}}$ is not deprotected in cells in the absence of light (Data not shown).

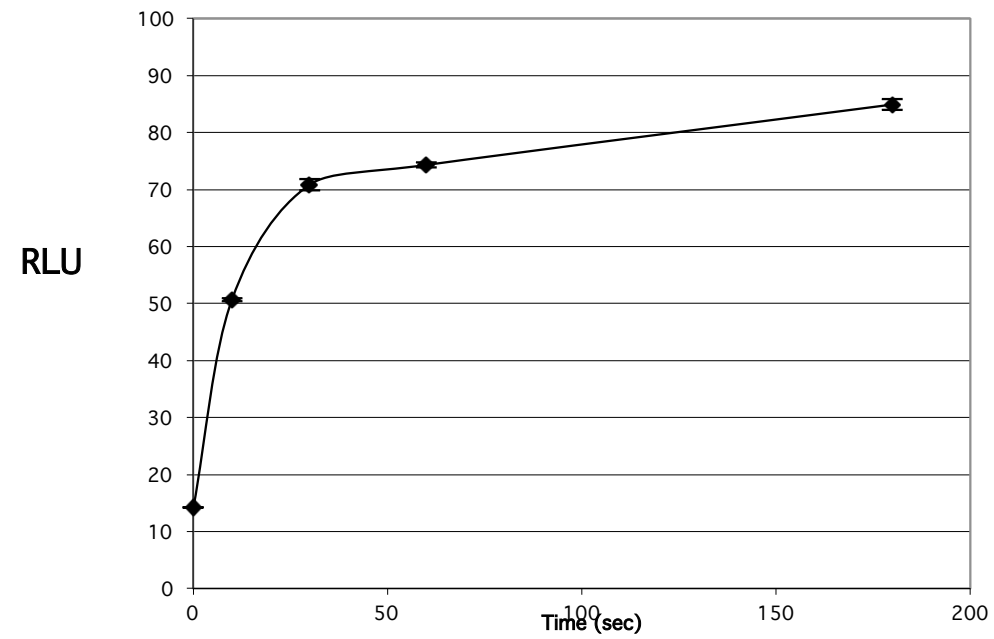

Figure 2.8: Exposure dependence of transactivation response of luciferase reporter gene in HEK293 cells.

The magnitude of light activated transcription response of ER $+\underline{\mathbf{1}}$ can be adjusted by the duration of exposure (Figure 2.8). The magnitude of transcription response can be adjusted between basal and 70\% with exposures between 0 and 30 seconds. After $30 \mathrm{~s}$ of exposure the response plateaus. This means that ER $+\underline{\mathbf{1}}$ is capable of rheostatic control and can be remotely adjusted by the action of light. This suggests that future applications of light-activated gene expression may include the 
patterning of gene expression gradients similar to those found in many in vivo systems provided that we can demonstrate spatial control.

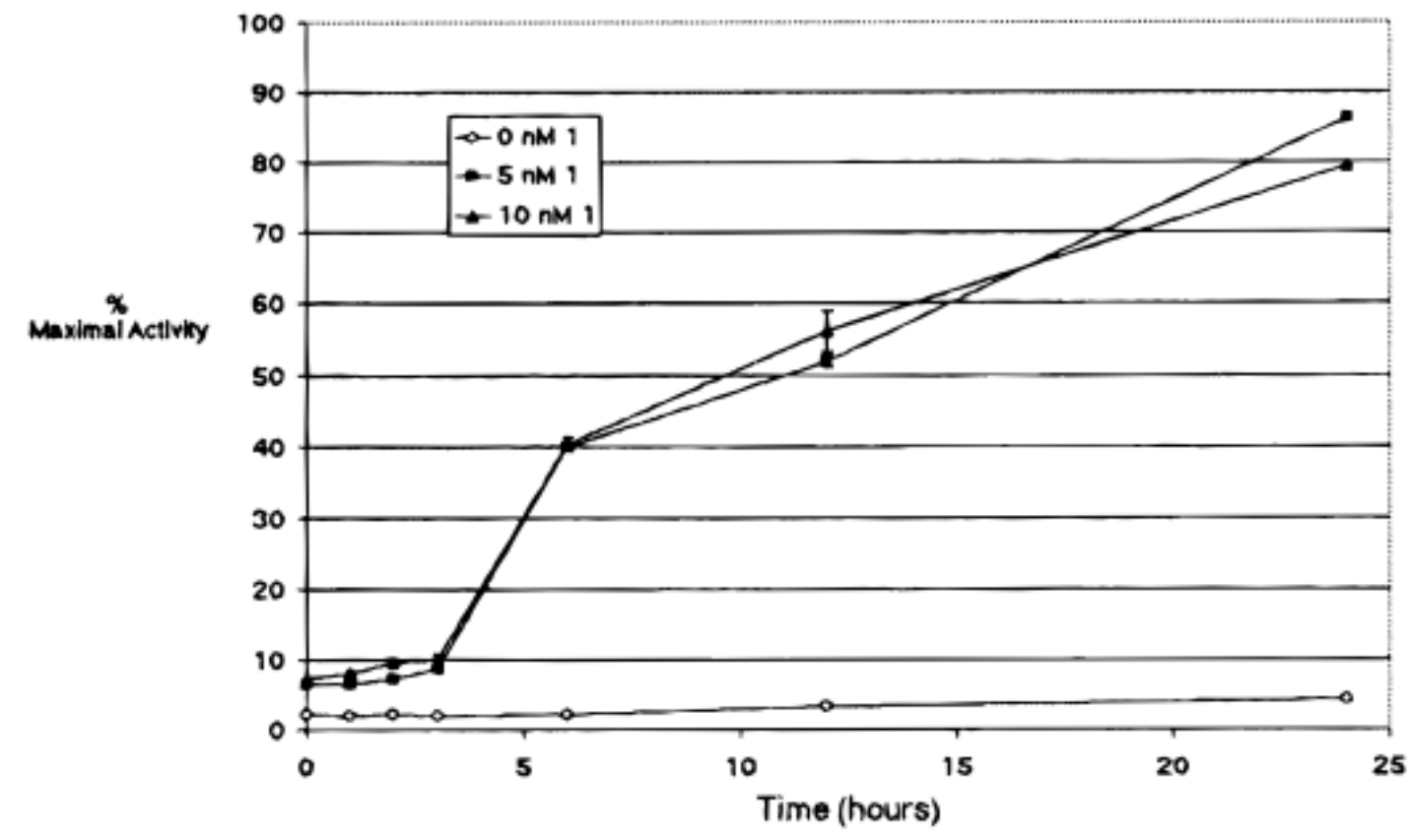

Figure 2.9: Time dependence of gene product formation after photo-release of estradiol.

We also examined the time course of reporter gene production by evaluating luciferase response at different time points after irradiation (Figure 2.9). No significant increase in transcription is observed in the absence of compound. A similar time-course and similar activation levels are obtained when using both $5 \mathrm{nM}$ and 10 $\mathrm{nM}$ caged compound, suggesting that $5 \mathrm{nM}$ effectively saturates the response for the first 3 hours before it rapidly rises and approaches a maximum after 24 hours. Not all 
hormone receptors show this induction period as we will later see with caged hormone receptor agonists for the thyroid and retinoic acid receptors.

This result shows that photocaged hormones can be used to place hormone responsive genes under the control of light. Whereas this experiment shows that we can use caged ligands to provide temporal control of gene expression, the rate of gene expression, initial transcription/translation, is rate limiting and a similar transcription response can be achieved by directly adding uncaged ligand to the media. A far more exciting application of light-activated gene expression would be the spatial and temporal control of genes which would require that the ligand be uncaged locally, preferably within the cell.

One of the most important issues of this project is determining if the synthetic ligand is really being deprotected inside the cell. Considerable effort was spent designing experiments that would allow us to demonstrate that the caged ligand is being uncaged inside the cell as opposed to being uncaged outside the cell and then diffusing in. We devised a simple wash-out experiment that involves monitoring the time-course of gene activation.

Having established the time-course for activation (see above Figure 2.9), we then repeated the experiment but included a "wash-out" step, a media exchange to ligand-free media, just prior to irradiation. By washing away the extracellular caged ligand just prior to irradiation, only intracellular ligand is present during the exposure. If the ligand is only uncaged outside the cell, we would expect little to no gene activation that would remain at a constant level. Whereas, if the ligand is deprotected 
inside the cell, we would expect an initial increase in gene expression that diminishes with time as the uncaged ligand is removed through diffusion and dilution into the bulk media. After a $12 \mathrm{~h}$ treatment with caged E2 1 the media was quickly changed to ligand free media and immediately irradiated for 12 minutes. After an initial induction, luciferase levels increased initially at a similar rate and level as cells that did not undergo the "wash-out" step (Figure 2.10). However, after 4 hours the luciferase levels drop, consistent with the loss of ligand to diffusion.

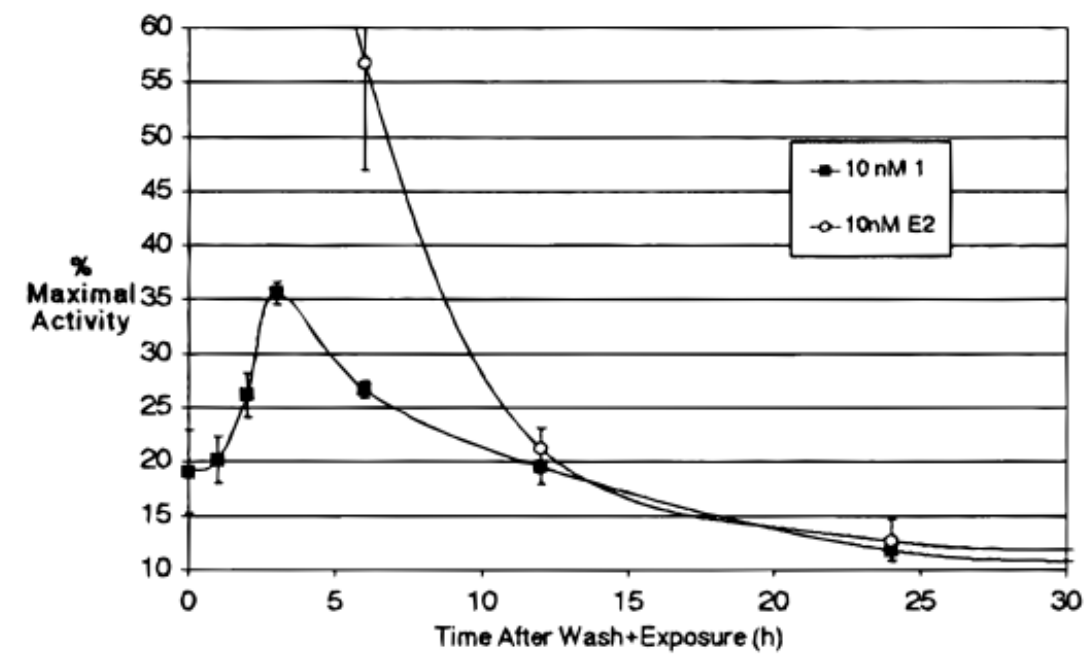

Figure 2.10: Time dependence of gene product formation after exposure. Cells incubated in $10 \mathrm{nM} \underline{1}$ or E2 are washed prior to a 12 minute UV exposure. 
As an additional control, cells were pre-treated with E2 (uncaged) for $12 \mathrm{~h}$ and were similarly "washed" to remove extracellular E2. The washed E2-treated cells lost their luciferase activity at a similar rate. While the rate of activity loss likely reflects the stability of the luciferase reporter gene, this data is consistent with a model where free E2 readily diffuses out of cells but not until after a sufficient amount locally initiates gene transcription.

Taken together these studies demonstrate that the caged ligand $\mathbf{1}$ is able to be uncaged within the cell, a critical criterion for later performing light-directed gene patterning. Others have adopted this same experimental design to demonstrate intracellular uncaging in their systems. ${ }^{13-14}$ Intramolecular uncaging ultimately means that enough of uncaged ligand can induce a cellular process in this case gene transcription prior to diffusion into the surrounding media.

Later studies by others in the Koh group and other labs used these foundational studies to develop other light-directed systems for controlling gene expression in cells using small-molecule effectors. Building upon these methods, this approach has been used for both eukaryotic and prokaryotic systems to control transcription and recombination to create spatially defined patterns in cell monolayers that could evaluate effects of specific genes on intercellular communication in vitro models. 


\subsection{Methods}

\subsubsection{Transient Transfection Assays (General Procedure)}

Twenty-four hours before transfection, HEK 293 cells were seeded to a density of approximately 40,000 cells per well in a 24 well culture plates (Costar \#3524) and grown in Dulbecco's Modified Eagle Medium (DMEM) without phenol red. The media was supplemented with 10\% fetal bovine serum (FBS) and gentamycin. Three hours prior to the transfection, the media was changed to DMEM containing $10 \%$ charcoal-resin stripped $\mathrm{FBS}^{10}$. The transfections were performed using calcium phosphate method. Six hours after the transfection, the media was removed and replace with media containing the appropriate concentration of ligand. All manipulations involving compound $\underline{\mathbf{1}}$ were in the dark with the use of a darkroom safelight. The cells were allowed to incubate with the new media for 12 hours followed by exposure to UV light. After the exposure, the cells were allowed to incubate for 48 hours before harvesting by passive lysis. The cell extracts were immediately assayed using the Dual Luciferase Assay (Promega) using a Dynex luminometer. Bioluminescence activity was reported in relative light units (RLU) determined as the ratio of the firefly luminescence divided by the luminescence of the renilla luciferase control. The bioluminescence activity was performed by running three replicates per sample. 


\subsubsection{UV Exposure of Cells}

Cells growing in the 24 well plates were placed on a $0.5 \mathrm{~cm}$ thick aluminum plate $4 \mathrm{~cm}$ below a UV lamp (Spectroline) that rests upon a $0.5 \mathrm{~cm}$ thick glass plate. The samples were irradiated through the culture plate lid for 3 or 12 minutes depending upon the experiment. The intensity of the UV lamp was determined to be $3000 \mathrm{mWatts}$ as measured by an all-wave UV intensity monitor from UltraLum. HPLC analysis of $1 \mathrm{mM}$ solutions of $\underline{1}$ in methanol exposed in 24 well culture plates show efficient conversion to estrogen.

\subsubsection{Exposure Dependence of Gene Product Formation}

Solutions of compound $\mathbf{1}$ in methanol $(1 \mathrm{mM})$ were irradiated in cell culture plates using the apparatus (shown above) and analyzed by HPLC. Compound $\underline{1}$ was converted to estradiol with an efficiency of $40 \%$ at a rate of $3 \times 10^{2} \mathrm{~s}^{-1}$. The effect of exposure time on gene product formation was measured by following the general transfection protocol mention above except that the cells were exposed for different exposure times of $0,10,30,60$, and 180 seconds. The cells were allowed to incubate 24 hours after exposure before harvesting by passive lysis and analyzed by Dual luciferase assay (Promega). 


\subsubsection{Determination of Intracellular De-protection by Prewashing}

In order to determine if the ligand was being deprotected inside the HEK 293 cells, the cells were transiently transfected with the receptor, reporter and control. The cells were seeded with approximately 40,000 cells per well in a 24 well culture plates. The cells were allowed to incubate for 12 hours in the presence of estradiol and compound $\underline{\mathbf{1}}$. The cells were washed with PBS buffer that was quickly replaced with new media without ligand. The irradiation was performed immediately after the media was exchanged. In this experiment, a 12 minute exposure time was used to ensure that compound 1 was completely deprotected. The cells were allowed to incubate for 0 to 36 hours before harvesting by passive lysis.

\subsubsection{Evaluating Compound Stability by Incubating in Cell Lysates}

In order to determine if the ligand was being deprotected in the cells in the absence of light, compound $\underline{\mathbf{1}}$ was pre-incubated in cell lysates and assayed for activity. Solutions of $\underline{1}$ at $0.2 \mathrm{uM}$ concentration were placed in media containing cell lysates from $1.4 \times 10^{7}$ of HEK 293 cells which were allowed to incubate for 36 hours at $37{ }^{\circ} \mathrm{C}$. From this stock solution, different solutions of media containing different ligand concentrations of $\underline{\mathbf{1}}$ were used $(1,5$, and $10 \mathrm{nM})$ and added to transfected cells and compared to cells grown in the presence of $\underline{1}$ which were not pretreated with lysates by our established luciferase assay protocol. Cells grown in the presence of lysate treated compound $\underline{1}$ show essentially identical activity as non-lysate treated $\underline{\mathbf{1}}$. 


\subsubsection{Antagonists Properties Assessed by Using Estradiol}

In order to determine if compound $\underline{\mathbf{1}}$ behaves as an agonist, antagonist, or a non-ligand, cells were grown in media containing $5 \mathrm{nM}$ estradiol plus different concentrations of $\underline{\mathbf{1}}(0,100,200,500,800$, and $1000 \mathrm{nM})$. The cells were transfected using the standard protocol and were allowed to incubate for 36 hours before they were lysed and assayed.

\subsubsection{Purity of Compound $\underline{1}$}

Compound 1 which was derived from estradiol could provide activities if contaminated by free estradiol. Analysis using normal-phase HPLC using a Shimadzu $\mathrm{SCl} 10 \mathrm{~A}$ HPLC with a UV detector $(284 \mathrm{~nm})$ can detect as little as amount $1 \mu \mathrm{M}$ estradiol under these conditions. Analysis of $1 \mathrm{mM}$ solution of 1 shows no estradiol which indicates that the sample contains less than $0.1 \%$ of estradiol which should not provide a significant response at the ligand concentrations used. Retention times for estradiol and compound $\underline{\mathbf{1}}$ are 13.6 minutes and 15.3 minutes respectively on normal phase (50:50 hexanes/ethyl acetate, $1 \mathrm{~mL} / \mathrm{min})$ with an Econosil Silica 5 u column from Alltech (Figure 2.11). 


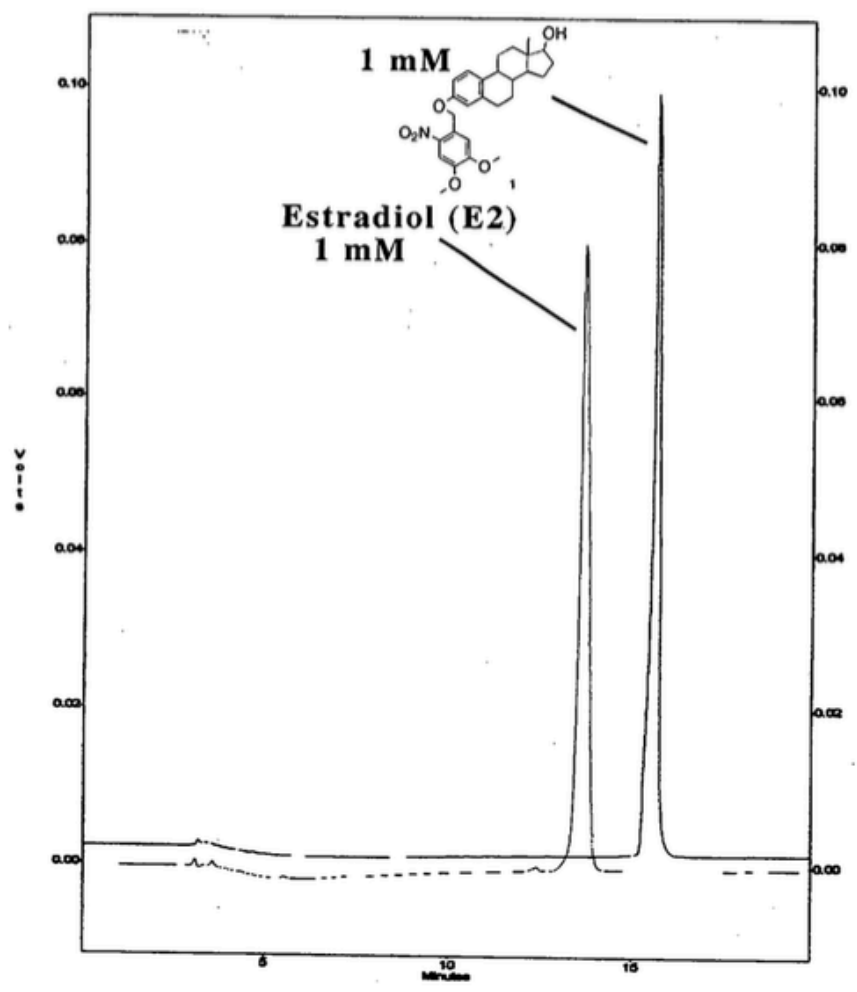

Figure 2.11: HPLC analysis of $\underline{\mathbf{1}}$ shows no visible contamination from estradiol.

\subsection{Synthesis}

\subsubsection{Preparation of 4,5-Dimethoxy-2-nitrobenzyl-estradiol (1)}

To a suspension of estradiol $(0.100 \mathrm{~g}, 0.37 \mathrm{mmol})$ and $\mathrm{K}_{2} \mathrm{CO}_{3}(0.100 \mathrm{~g}, 0.73$ $\mathrm{mmol}$ ) in $3 \mathrm{~mL}$ of dry acetone was added to a solution of 4,5-dimethoxy-2nitobenzylbromide $(0.100 \mathrm{~g}, 0.37 \mathrm{mmol})$ in $1 \mathrm{~mL}$ of dry acetone at ambient temperature under an inert atmosphere. After addition, the reaction was allowed to stir for 3 hours and monitored by TLC until complete consumption of the starting material 
was observed. The mixture was extracted with ethyl acetate $(10 \mathrm{~mL})$. The organic layer was then washed with water $(2 \times 10 \mathrm{~mL})$ and saturated brine $(10 \mathrm{~mL})$ and dried over $\mathrm{Na}_{2} \mathrm{SO}_{4}$. After concentration in vacuo, the crude product was purified by silica flash chromatography (50\% ethyl acetate in hexanes) that afforded $\underline{1}$ as a light yellow solid (0.116 g, 67.1\% yield).

1H NMR (400 MHz, $\left.\mathrm{CDCl}_{3}\right)$

d $0.78(\mathrm{~s}, 3 \mathrm{H}), 1.18-2.35(\mathrm{~m}, 14 \mathrm{H}), 2.86(\mathrm{~m}, 1 \mathrm{H}), 3.73(\mathrm{dd}, \mathrm{J}=5.7,5.7 \mathrm{~Hz}, 1 \mathrm{H}), 3.97$

(s, 6H), $5.46(\mathrm{~s}, 2 \mathrm{H}), 6.74(\mathrm{~d}, \mathrm{~J}=2.68 \mathrm{~Hz}, 1 \mathrm{H}), 6.78-6.83(\mathrm{dd}, \mathrm{J}=2.71,2.83 \mathrm{~Hz}, 1 \mathrm{H})$,

$7.21(\mathrm{~d}, \mathrm{~J}=8.62 \mathrm{~Hz}, 1 \mathrm{H}), 7.42(\mathrm{~s}, 1 \mathrm{H}), 7.77(\mathrm{~s}, 1 \mathrm{H})$

13C NMR (100 MHz, $\left.\mathrm{CDCl}_{3}\right)$

d 169.1, 162.3, 147.7, 138.3, 129.4, 114.9, 112.5, 109.4, 107.9, 81.9, 67.1, 56.4, 50.0, $43.9,43.2,38.7,36.7,30.6,29.8,29.7,26.3,23.1,11.0$

HR MS (FAB) calcd for $\mathrm{C}_{27} \mathrm{H}_{34} \mathrm{~N}_{1} \mathrm{O}_{6}\left(\mathrm{MH}^{+}\right)$:468.2386 found: 468.2387

Note: Selective alkylation of the phenolic 1-hydroxyl without reacting the hydroxyl at position 17 is well precedented. ${ }^{11-12}$ Nonetheless, selective alkylation at position $\underline{\mathbf{1}}$ was verified by noting the induced chemical shift changes of the aryl protons ortho to the site of substitution (Figure 2.14) 


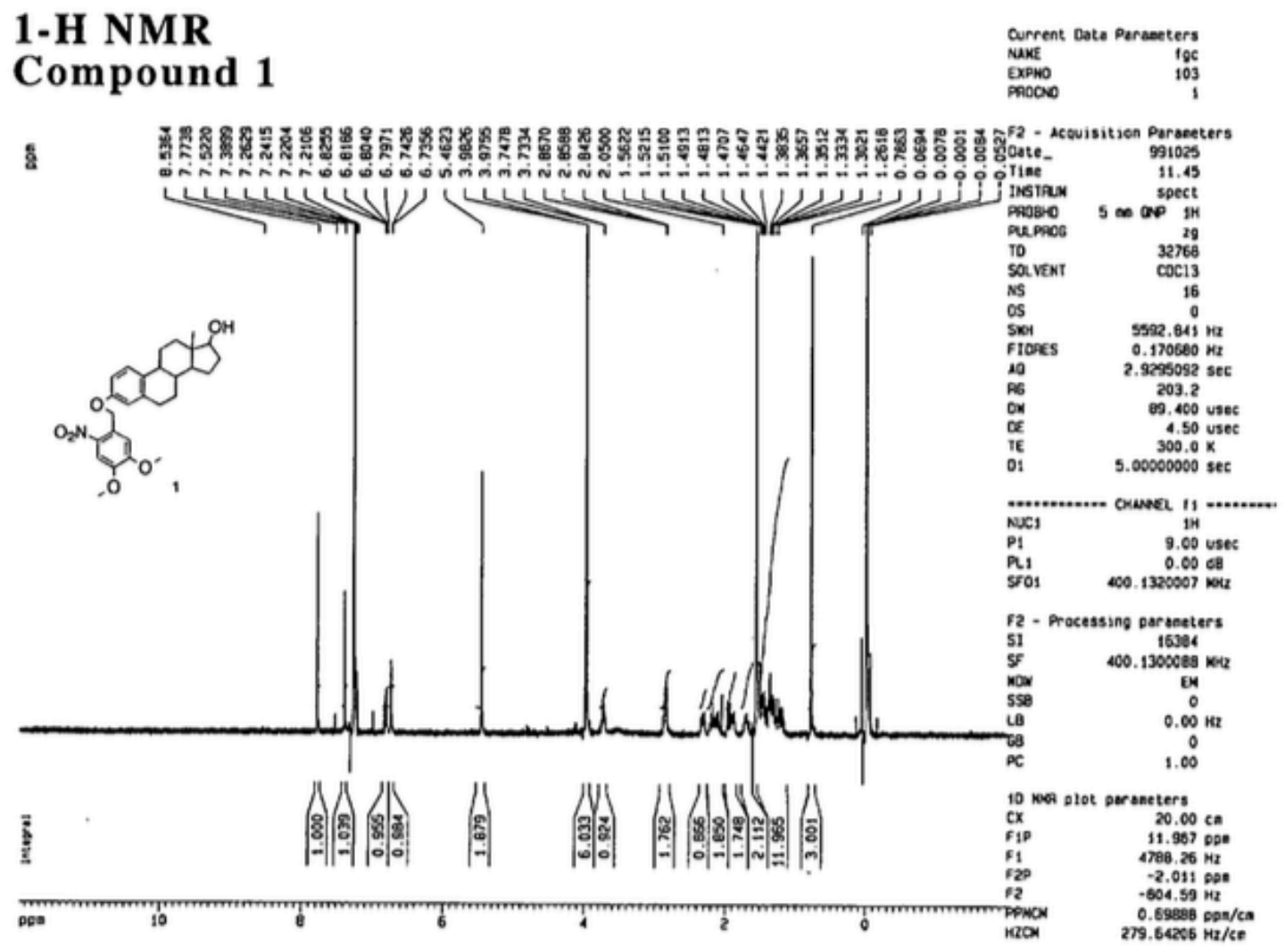

Figure 2.12: 1H NMR 


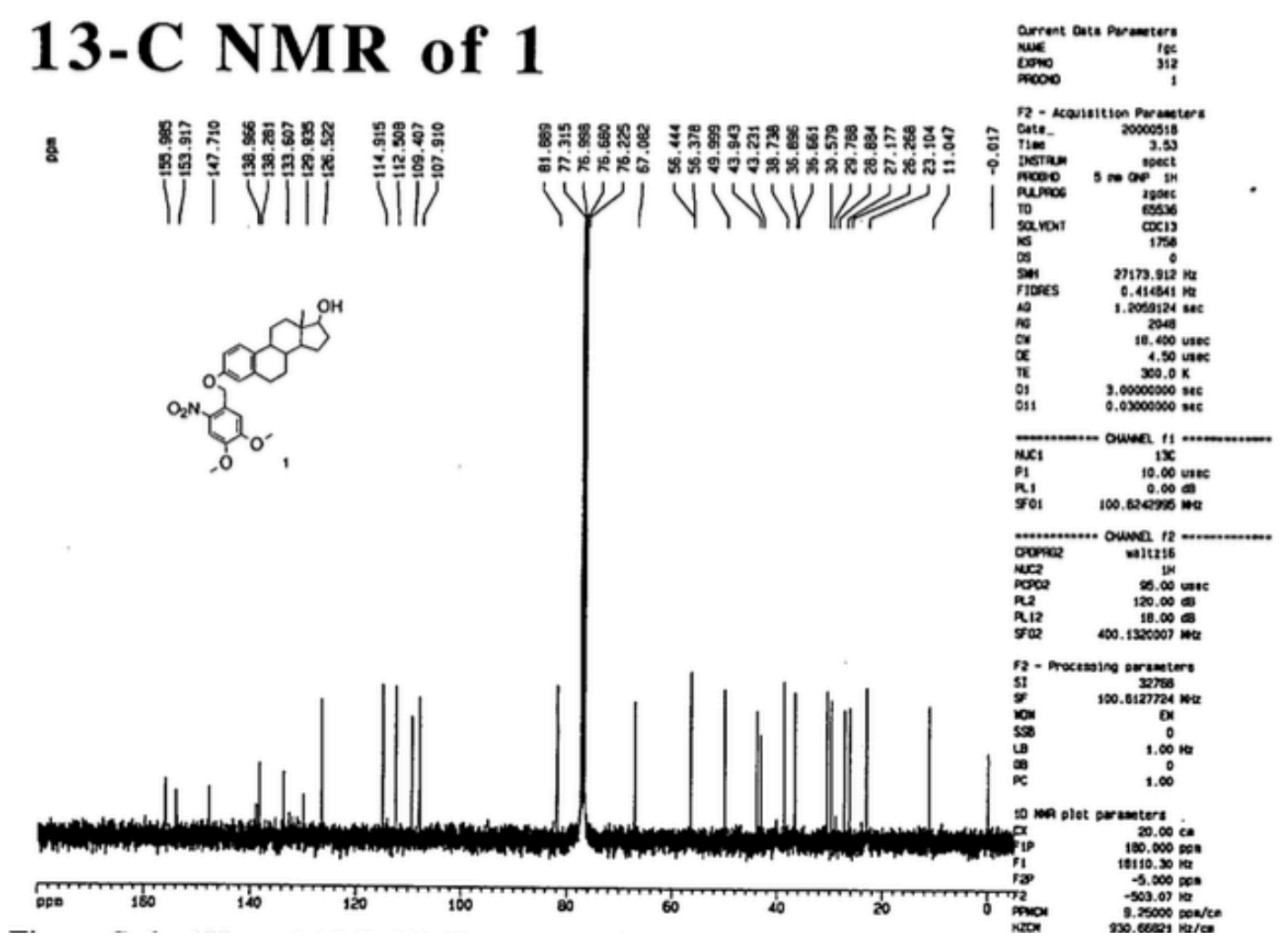

Figure 2.13: 13C NMR 

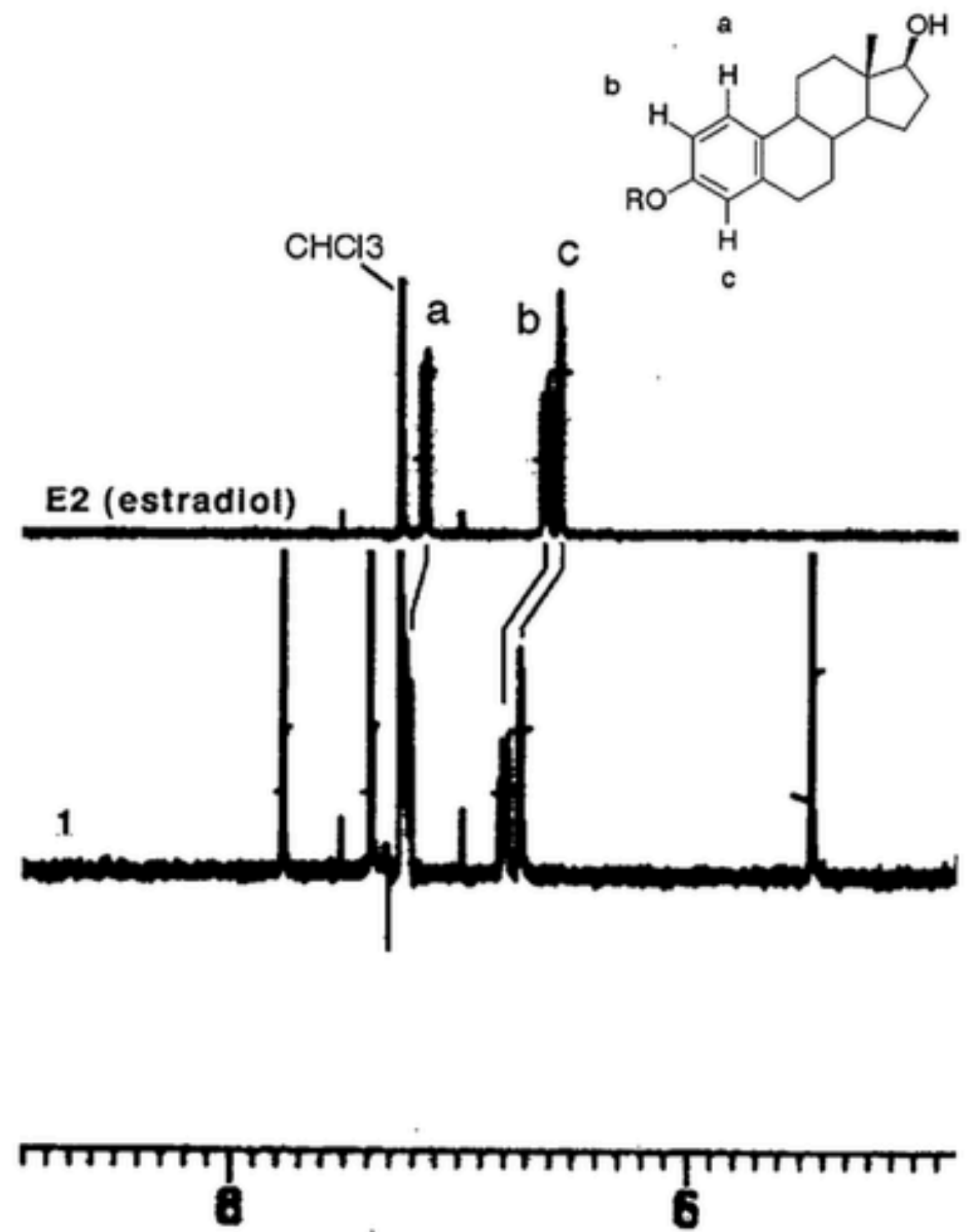

Figure 2.14: Comparison of alkylation at the 1-hydroxyl position between estradiol and compound $\underline{\mathbf{1}}$. 


\section{REFERENCES}

1. Kumar, V.; Green, S.; Stack, G.; Berry, M.; Jin, J.; Chambon, P., Functional domains of the human estrogen-receptor. Cell 1987, 51 (6), 941-951.

2. Marino, M.; Galluzzo, P.; Ascenzi, P., Estrogen signaling multiple pathways to impact gene transcription. Current Genomics 2006, 7 (8), 497-508.

3. Schwabe, J.; Chapman, L.; Finch, J.; Rhodes, D., The crystal-structure of the estrogen-receptor DNA-binding domain bound to DNA - How receptors discriminate between their response elements. Cell 1993, 75 (3), 567-578.

4. Brzozowski, A.; Pike, A.; Dauter, Z.; Hubbard, R.; Bonn, T.; Engstrom, O.; Ohman, L.; Greene, G.; Gustafsson, J.; Carlquist, M., Molecular basis of agonism and antagonism in the oestrogen receptor. Nature 1997, 389 (6652), 753-758.

5. Pike, A.; Brzozowski, A.; Hubbard, R.; Bonn, T.; Thorsell, A.; Engstrom, O.; Ljunggren, J.; Gustafsson, J.; Carlquist, M., Structure of the ligand-binding domain of oestrogen receptor beta in the presence of a partial agonist and a full antagonist. Embo Journal 1999, 18 (17), 4608-4618.

6. Moras, D.; Gronemeyer, H., The nuclear receptor Ligand-binding domain of estrogen receptors. Current Opinion in Biotechnology 1999, 10 (6), 550-556.

7. Nilsson, S.; Makela, S.; Treuter, E.; Tujague, M.; Thomsen, J.; Andersson, G.; Enmark, E.; Pettersson, K.; Warner, M.; Gustafsson, J., Mechanisms of estrogen action. Physiological Reviews 2001, 81 (4), 1535-1565.

8. Tora, L.; Mullick, A.; Metzger, D.; Ponglikitmongkol, M.; Park, I.; Chambon, P., The cloned human estrogen-receptor contains a mutation which alters its hormone binding-properties. Embo Journal 1989, 8 (7), 1981-1986.

9. Thompson, J.; Hayes, L.; Lloyd, D., Modulation of firefly luciferase stability and impact studies of gene-regulation. Gene 1991, 103 (2), 171-177.

10. Samuels, H.; Stanley, F.; Casanova, J., Depletion of L-3,5,3'-triiodothyronine and L-thyroxine in euthyroid calf serum for use in cell-culture studies of the action of thyroid-hormone. Endocrinology 1979, 105 (1), 80-85.

11. Pejanovic, V.; Petrovic, J.; Csanadi, J.; Stankovic, S.; Miljkovic, D., Synthesis and unusual Beckmann fragmentation reaction of syn-3-methoxy-6-alpha, 17-betadihydroxyestra-1,3,5(10)-trien-7-one oxime. Tetrahedron 1995, 51 (48), 13379-13384. 
12. Lee, Y.; Shimizu, I., Convenient O-methylation of phenols with dimethyl carbonate. Synlett 1998, (10), 1063-+.

13. Lin, W.; Albanese, C.; Pestell, R.; Lawrence, D., Spatially discrete, light-driven protein expression. Chemistry \& Biology 2002, 9 (12), 1347-1353.

14. Cambridge, S.; Geissler, D.; Keller, S.; Curten, B., A caged doxycycline analogue for photoactivated gene expression. Angewandte Chemie-International Edition 2006, 45 (14), 2229-2231. 


\section{Chapter 3}

\section{PHOTO-CAGED AGONISTS OF THE NUCLEAR RECEPTORS: RETINOID ACID (RAR) AND THYROID (TR)}

\subsection{Introduction}

As shown in the previous chapter, light-activated gene expression provides a method to remotely regulate the expression of specific genes and provide a powerful tool to elucidate the role of specific genes involved in differentiation, growth and homeostasis. ${ }^{1-7}$ The actions of many gene products crucial for the development and homeostasis are only revealed through their unique spatial and temporal patterns of expression. ${ }^{8-10}$

Therefore the photo-regulation of signal transduction and/or gene expression provides an exciting new tool for the study of gene function that can provide both spatial and temporal control of gene expression. Several studies have shown that expression of some genes can be regulated by light using photo-caged molecules such as enzymes, nucleic acids, or even plant phytochromes involved in signalling pathways. $^{11-14}$

In this chapter, we will look at applying our light-activated gene expression method to photocaged agonists of the retinoic acid receptor (RAR) and the thyroid hormone receptor (TR). These receptor-agonist pairs can be studied in closely related experimental systems using the same cell line and exploiting the well-known 
phenomenon that RAR and TR can both regulate reporter gene expression from the identical DR4 hormone response element. ${ }^{15-18}$

\subsection{Photo-stable Agonists of Retinoid and Thyroid Receptors}

The natural ligands for the retinoic acid and thyroid nuclear hormone receptors are light sensitive. Retinoic acid contains a light sensitive polyene and triiodothyronine contains aryl iodides that are sensitive to photo-isomerization or degradation. Therefore, photo-caged analogs of the known photostable agonists of RAR and TR were synthesized. ${ }^{19-20}$

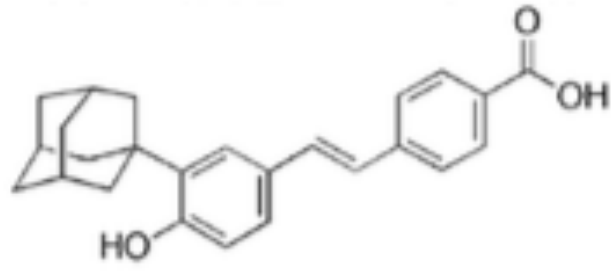

1

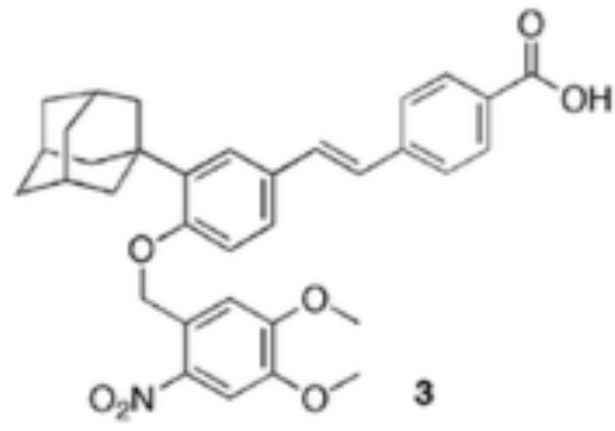<smiles>Cc1cc(OCC(=O)O)cc(C)c1Cc1ccc(O)c(C(C)C)c1</smiles>

2, (GC1)<smiles>COc1cc(COc2ccc(Cc3c(C)cc(OCC(=O)O)cc3C(C)C)cc2C)c([N+](=O)[O-])cc1OC</smiles>

Figure 3.1: Light-stable agonists and photo-caged analogs 

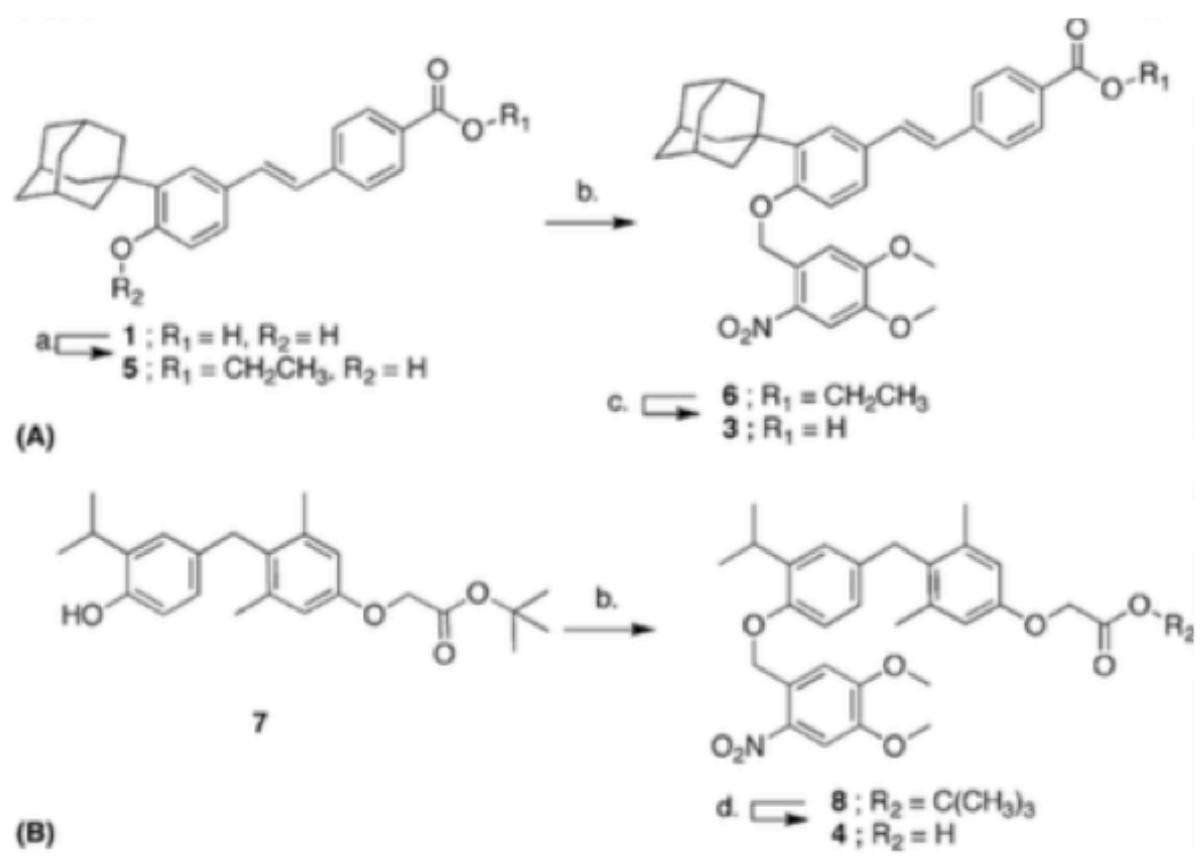

Figure 3.2: Synthesis of caged agonists $\underline{\mathbf{3}}$ in scheme (A) and $\underline{\mathbf{4}}$ in scheme (B).

Reagents and conditions: (a) $\mathrm{H}_{2} \mathrm{SO}_{4}$, EtOH, reflux (86\%), (b) $\mathrm{K}_{2} \mathrm{CO}_{3}$, 4,5dimethoxylnitrobenzyl bromide, $\operatorname{DMF}(91 \%)$, (c) $\mathrm{LiOH}, \mathrm{THF} / \mathrm{H}_{2} \mathrm{O}(75 \%)$, (d) $\mathrm{NaOH}$, rt $(95 \%)$.

\subsection{Photo-caged Agonists Efficiently Release Photo-stable Agonists in vitro}

The use of known synthetic agonists of RAR and TR was used in these experiments. The stilbene $\underline{\mathbf{1}}$ (Figure 3.1) is a known agonist for RAR and has an $\mathrm{EC}_{50}$ of $700 \mathrm{nM} .{ }^{19}$ The photocaged analog $\underline{\mathbf{3}}$ was synthesized by transient protection of the carboxyl group as the ethyl ester followed by direct alkylation of the phenol (Figure $3.2 \mathrm{a})$. 
Compound 2, also known as GC-1, is a known agonist of TR $\beta$ with an $\mathrm{EC}_{50}$ of $31 \mathrm{nM}^{20-21}$ Compound $\underline{4}$ was synthesized from the t-butyl ester $\underline{\mathbf{7}}$, a key intermediate in the synthesis of GC-1. Both $\underline{\mathbf{3}}$ and $\underline{\mathbf{4}}$ were carefully purified by chromatography performed in the dark (or under red safe-light).

These caged ligands were deprotected under cell-free conditions to determine their rate and efficiency of product formation upon exposure to UV light. These compounds were evaluated by HPLC to confirm that compounds $\underline{3}$ and $\underline{4}$ photodeprotect to their agonist forms. Under identical conditions, the rate of deprotection of compounds $\underline{\mathbf{3}}$ and $\underline{\mathbf{4}}$ differ; $1.1 \times 10^{-2} \mathrm{~s}^{-1}$ for $\underline{\mathbf{4}}$ and $3.1 \times 10^{-2} \mathrm{~s}^{-1}$ for compound $\underline{\mathbf{3}}$ (Figure $3.3)$.

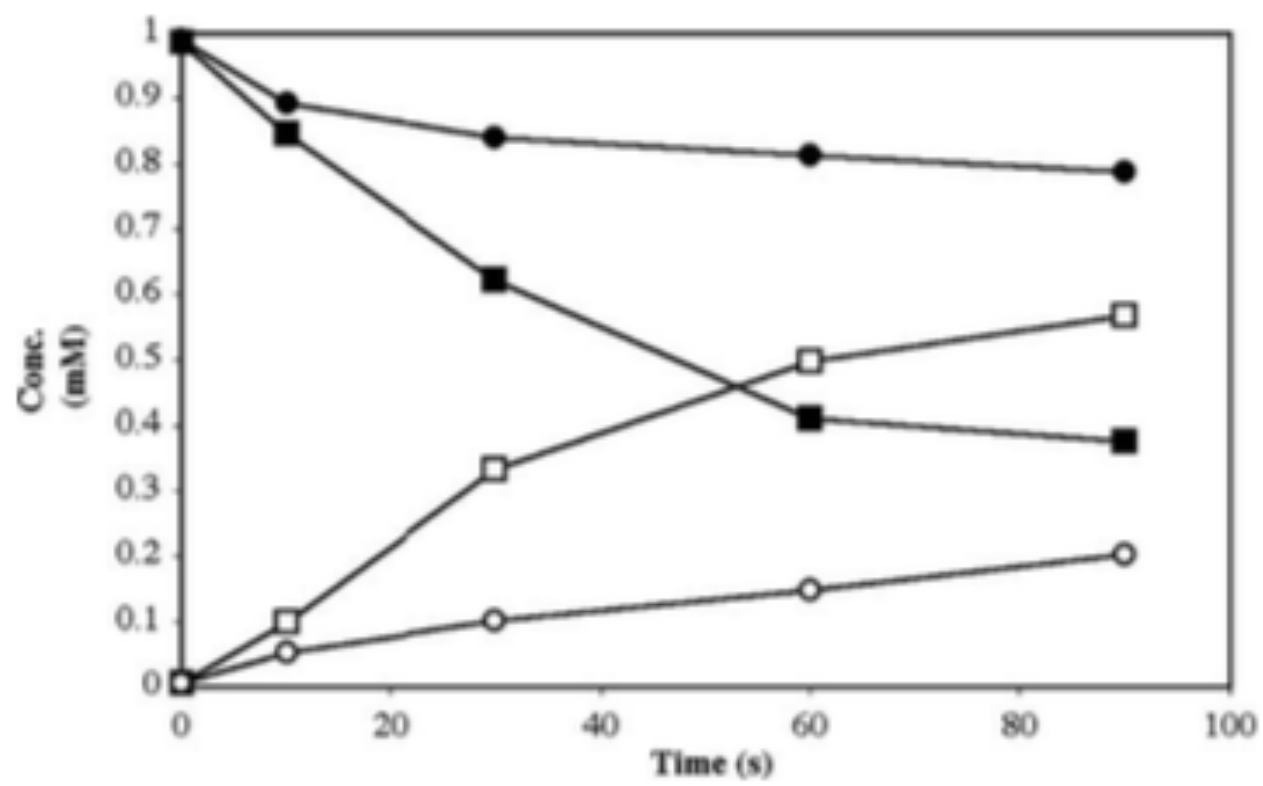

Figure 3.3: Exposure dependence of photodeprotection and product formation. Compounds $\underline{\mathbf{3}}(\boldsymbol{O})$ and $\underline{\mathbf{4}}(\boldsymbol{\square})$ are converted to agonists $\underline{\mathbf{1}}(\mathrm{O})$ and $\underline{\mathbf{2}}(\square)$. 
After a 90 s exposure approximately $20 \%$ of compound $\underline{\mathbf{3}}$ is converted to compound $\underline{\mathbf{1}}$ with greater than $90 \%$ chemical yield. In contrast, $90 \mathrm{~s}$ exposure of $\underline{4}$ leads to greater than $50 \%$ conversion to $\underline{\mathbf{2}}$ (GC-1) also with greater than $90 \%$ chemical yield. It is worth noting that although the two compounds share the same chemical protecting group, the rates of photo-deprotection differ significantly.

\subsection{Photo-caged Ligands are Stable under Cellular Conditions}

The photocaged ligands must remain stable under cellular conditions until the cells are exposed to UV irradiation. To test their cellular stability, the compounds were placed in HeLa cell lysates for 36 hours at $37^{\circ} \mathrm{C}$. Even small traces of the active ligand could activate the transcriptional machinery therefore solutions of the lysatetreated compounds were tested for their ability to induce gene transcription through the use of luciferase reporter gene assays. In addition, cells grown in either lysatetreated or untreated photocaged compounds show similar levels of gene expression after exposure to UV light. This shows that the caged compounds were neither decomposed nor deprotected in cell lysates (Figure 3.4). 

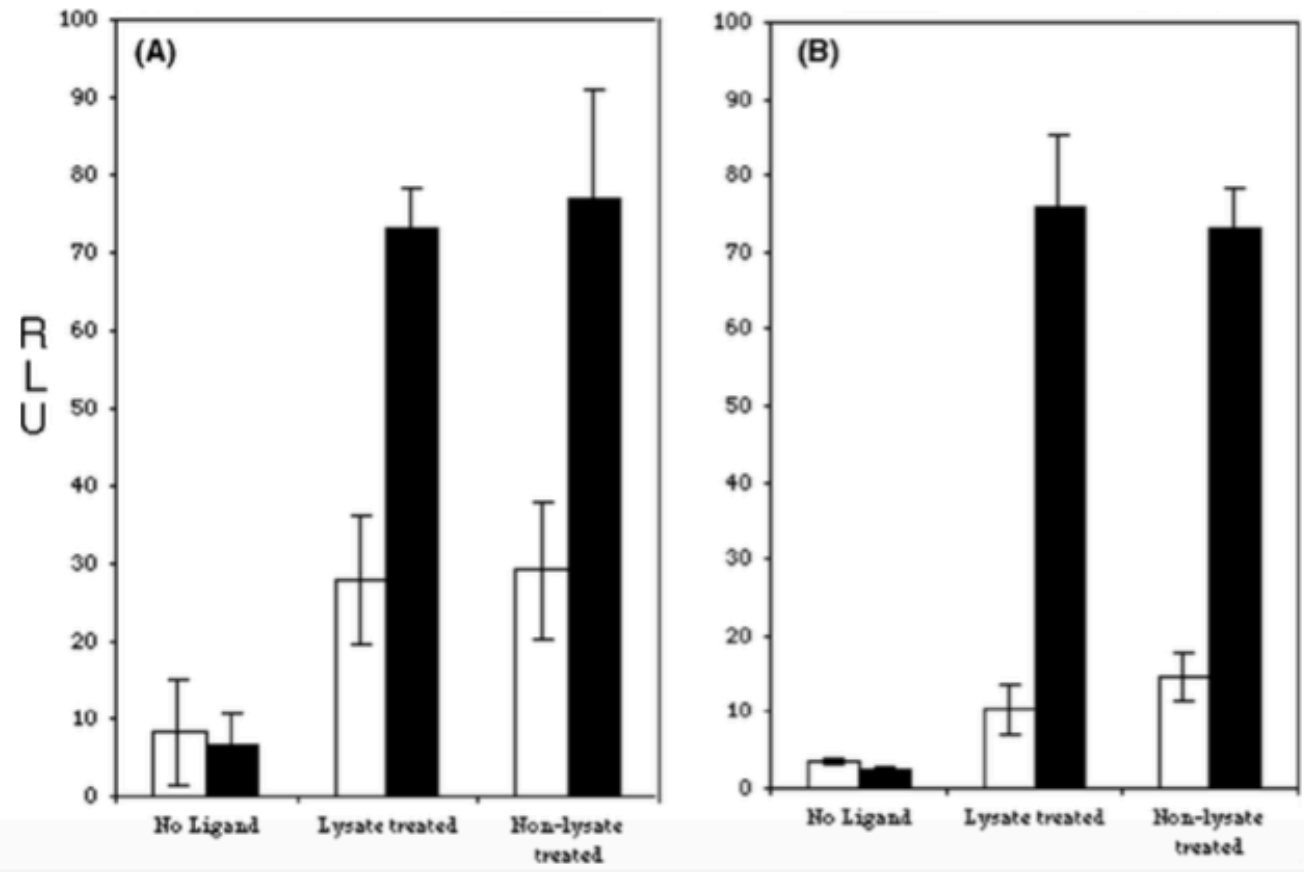

Figure 3.4: Treatment of photocaged ligands $(\underline{\mathbf{3}} \& \underline{\mathbf{4}})$ with cell lysates does not effect transactivation function in unexposed cells. (A) HeLa cells transfected with RAR reporter gene and incubate with compound $\underline{3}$. (B) HeLa cells transfected with the TR reporter and incubate with compound 4 . White bars are unexposed cells and black bars are exposed cells.

\subsection{Photo-caged Ligands Do Not Act as Agonists or Antagonists with Receptors Below $1 \mu \mathrm{M}$}

An important requirement for our caged compounds is that they should not act as agonists or antagonists prior to irradiation/deprotection. Therefore, HeLa cells were transfected with a luciferase reporter gene responsive to RAR and TR, as well as expression constructs for TR and RAR, and treated with increasing concentrations of 
the photocaged compounds. At $1 \mu \mathrm{M}$ or below, there was negligible increase in reporter gene expression indicating that the nitroveratryl protecting group on the phenol hydroxyl of compounds $\underline{\mathbf{1}}$ and $\underline{\mathbf{2}}$ is effectively masking the activity of the parent agonists. In addition, at higher concentrations such as $2500 \mathrm{nM}$, compounds $\underline{\mathbf{3}}$ and $\underline{4}$ gave a larger response in the reporter gene activity; suggesting that these molecules may be very weak agonists or may still contain trace amounts of the parent agonist. Finally, at even higher concentrations, such as 3000 and 4000 nM, visible signs of cellular toxicity (detached or malformed cells) were observed. Due to these results the photocaged ligands were used at concentration at or below $1000 \mathrm{nM}$ as shown in Figure 3.5 .

Additionally, the photocaged compounds $\underline{\mathbf{3}} \& \underline{\mathbf{4}}$ were tested for their ability to be antagonists in competition with their parent agonists $\underline{\mathbf{1}} \& \underline{\mathbf{2}}$. Again, HeLa cells were transfected with luciferase reporter gene for RAR or TR and incubated with the respective agonist plus increasing concentrations of photocaged compounds. No change in reporter gene expression was observed below $1000 \mathrm{nM}$ indicating that these compounds do not act as effective antagonists as shown in Figure 3.6. 

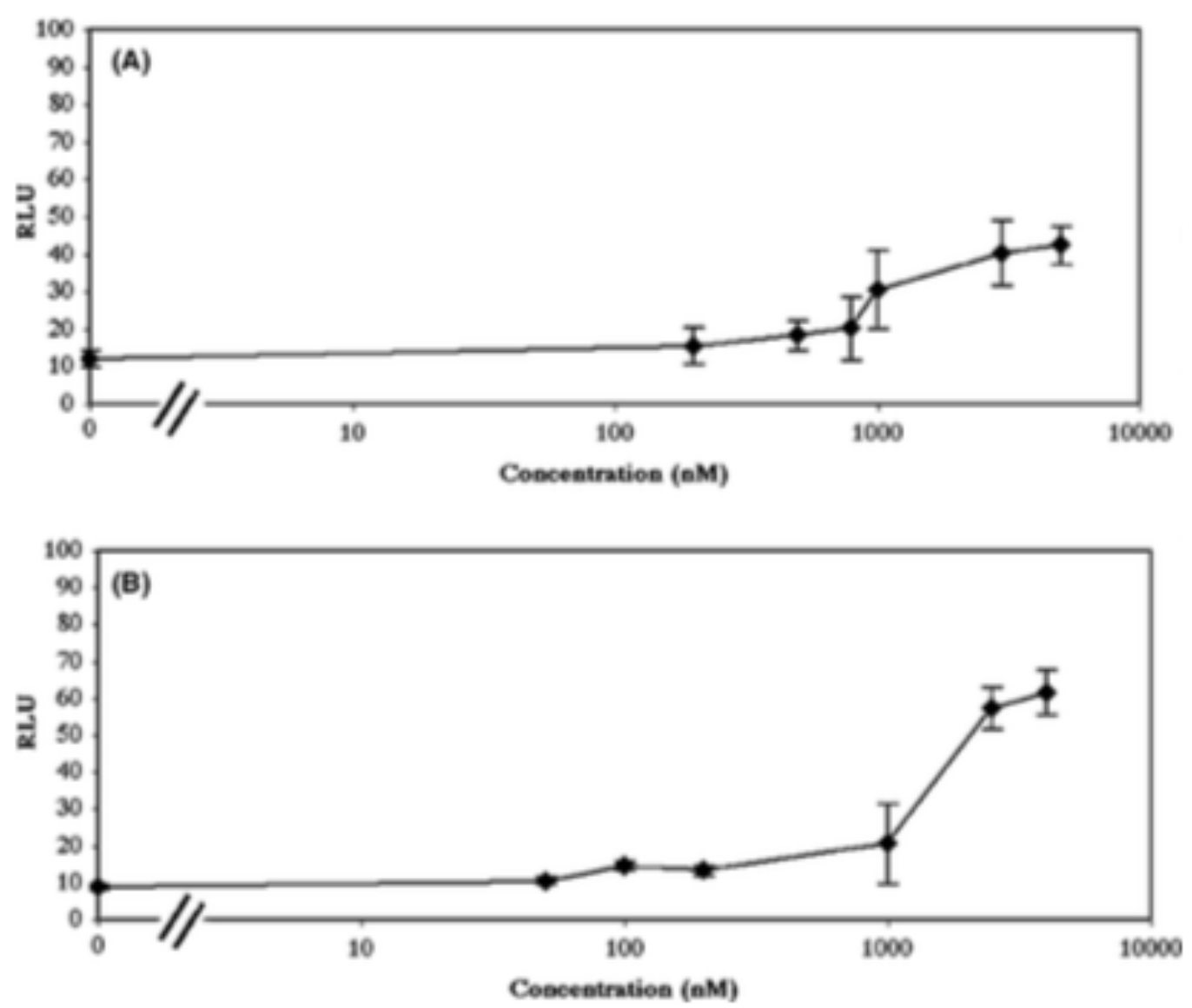

Figure 3.5: Photocaged compounds $\underline{3}$ and $\underline{4}$ show very little transcriptional activity below $1000 \mathrm{nM}$ in cells expressing (A) RAR or (B) TR. 

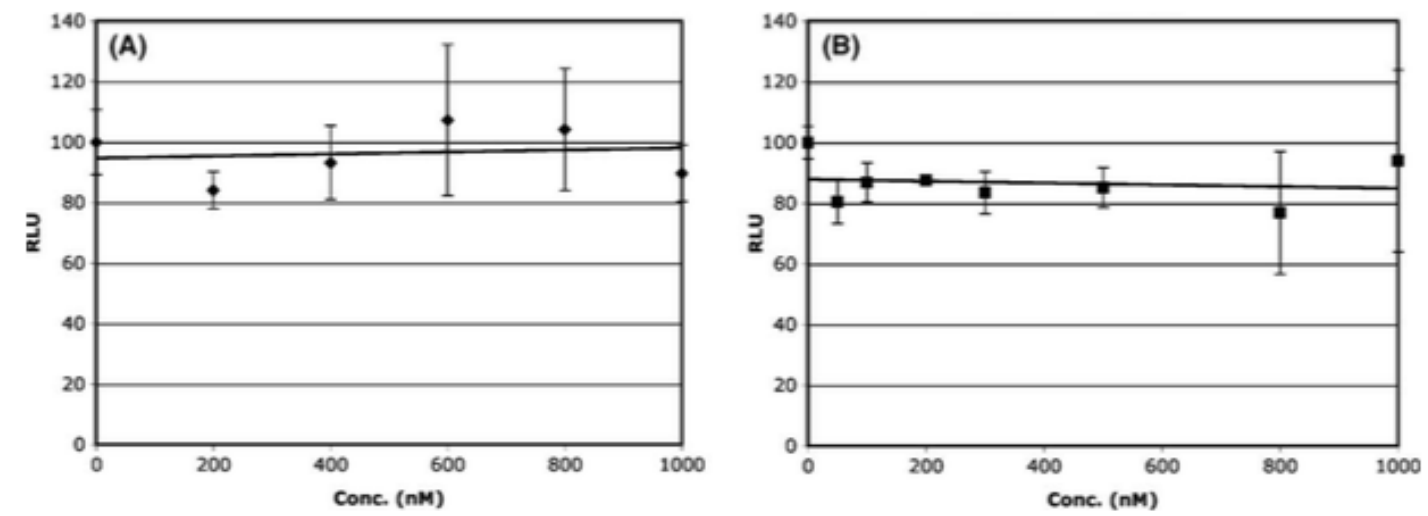

Figure 3.6: Compounds $\underline{\mathbf{3}} \& \underline{\mathbf{4}}$ do not antagonize RAR or TR dependent transactivation. (A) Cells expressing RAR treated with $800 \mathrm{nM}$ of $\underline{1}$ and increasing concentrations of $\underline{\mathbf{3}}$ and (B) cells expressing TR treated with $100 \mathrm{nM}$ of $\underline{\mathbf{2}}$ and increasing concentrations of $\underline{4}$.

\subsection{Caged Ligands Can Mediate Exposure Dependent RAR and TR Dependent Transactivation Response}

Cells transiently transfected with the reporter gene for either the RAR or TR were grown without ligand to make certain that there is no activity of the reporter after exposure. Exposure times greater than 5 minutes show some visible changes with the cell morphology or viability. Due to this results, exposure times were kept under 90 seconds or less to prevent any deleterious effects to the cells.

Cells were transfected with the reporter gene for either the RAR or TR were grown with either $800 \mathrm{nM}$ of $\underline{\mathbf{3}}$ or $500 \mathrm{nM}$ of $\underline{\mathbf{4}}$. The cells were irradiated for 90 seconds deprotecting compounds into $\underline{\mathbf{1}}$ and $\underline{\mathbf{2}}$. Both ligands show transactivation after exposure (see Figure 3.7). 

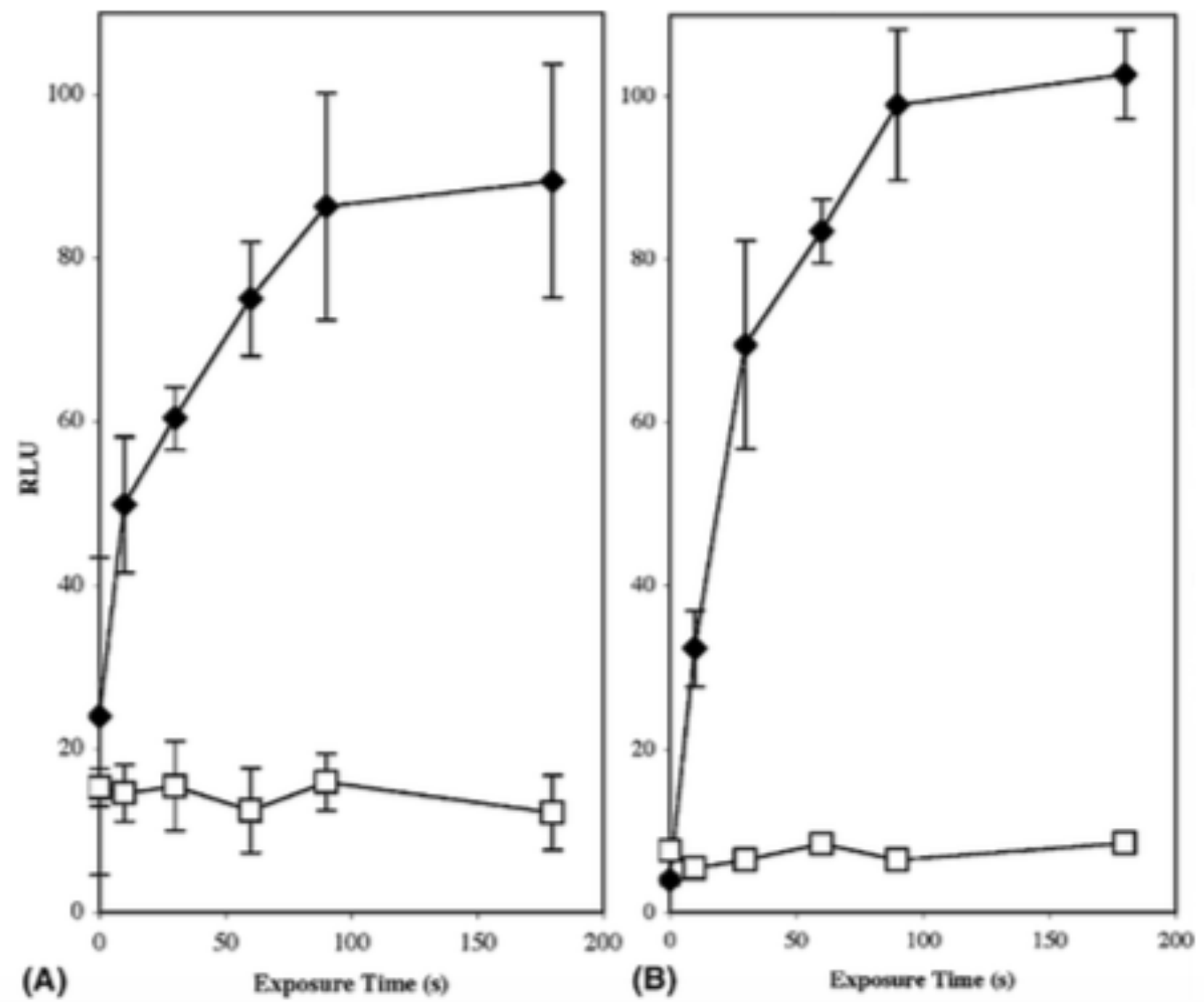

Figure 3.7: Gene expression activity determined 24 hours after exposure. (A) Cells expressing RAR reporter gene with $800 \mathrm{nM}$ of $\underline{\mathbf{3}}$ (b) or no ligand added (c). (B) Cells expressing TR reporter gene with $500 \mathrm{nM}$ of 4 (b) or no ligand added (c). Dark diamonds are exposed cells and white squares are unexposed cells.

The figure above shows a modest 4-fold induction of (A) RAR due to the large background activity observed with no ligand added versus (B) where the cells treated with compound $\underline{4}$ show a gene expression at a 24 -fold induction. 


\subsection{Intracellular Uncaging Provides a Transient Transactivation Response}

The application of photo-caged hormone receptor agonists to form spatially discrete patterns of gene expression maybe limited by the diffusion of the ligand out of the cells after deprotecting intracellularly. To find out where the uncaged ligand resides, inside or outside the cell, the following experiment was conducted. HeLa cells were grown in six-well plates with media containing one of the photocaged ligands for 12 hours. Before exposure, the media was removed and the cells were washed twice with PBS buffer, which was then replaced with fresh media without photo-caged compounds. Therefore, only the uncaged ligand is located intracellularly. The fluorescent properties of compound $\underline{1}$ allows for the direct intracellular visualization. Cells grown in the presence of $\underline{\mathbf{1}}$ show an intense intracellular fluorescence demonstrating that these compounds localize in the cytoplasm and are not associated with the membrane or cell surface after media was exchange. (See Figure 3.8) 


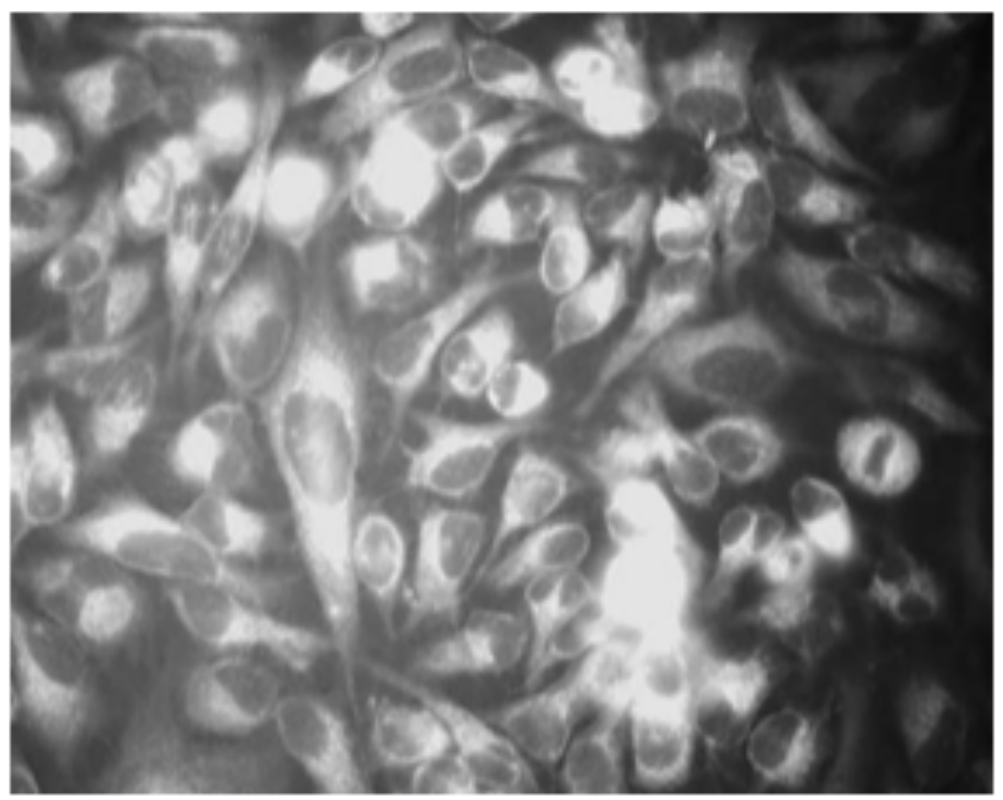

Figure 3.8: Fluorescence micrograph of HeLa cells incubated with compound $\underline{1}$ and observed under upright microscope with dipping lens.

HeLa cells pretreated with $800 \mathrm{nM} \mathbf{3}$ and 'washed' prior to irradiation for 90 seconds, show a unique temporal dependence of gene expression. After exposure, luciferase activity increases over the initial 4 hours at a rate similar to cells treated with compound $\underline{\mathbf{3}}$ but not washed prior to exposure. The gene expression product increases to a maximum at 6 hours and then decreases gradually due to the loss of the ligand by diffusion (Figure 3.9A). Therefore, the duration of the transcription response, measured as the length of time gene product gives us $50 \%$ of the maximum level or greater, is limited to approximately two hours. This response is similar to previously reported transcription response for ER and EcR therefore the RAR lightactivated system will not be practical method to pattern expression in multiple tissues. 
Cells expressing TR provide an intense, long duration of gene expression response.

TR shows a unique expression profile when HeLa cells are treated with $500 \mathrm{nM}$ of $\underline{4}$ that differs greatly from RAR with compound $\underline{\mathbf{3}}$ at $800 \mathrm{nM}$ in both duration and intensity.
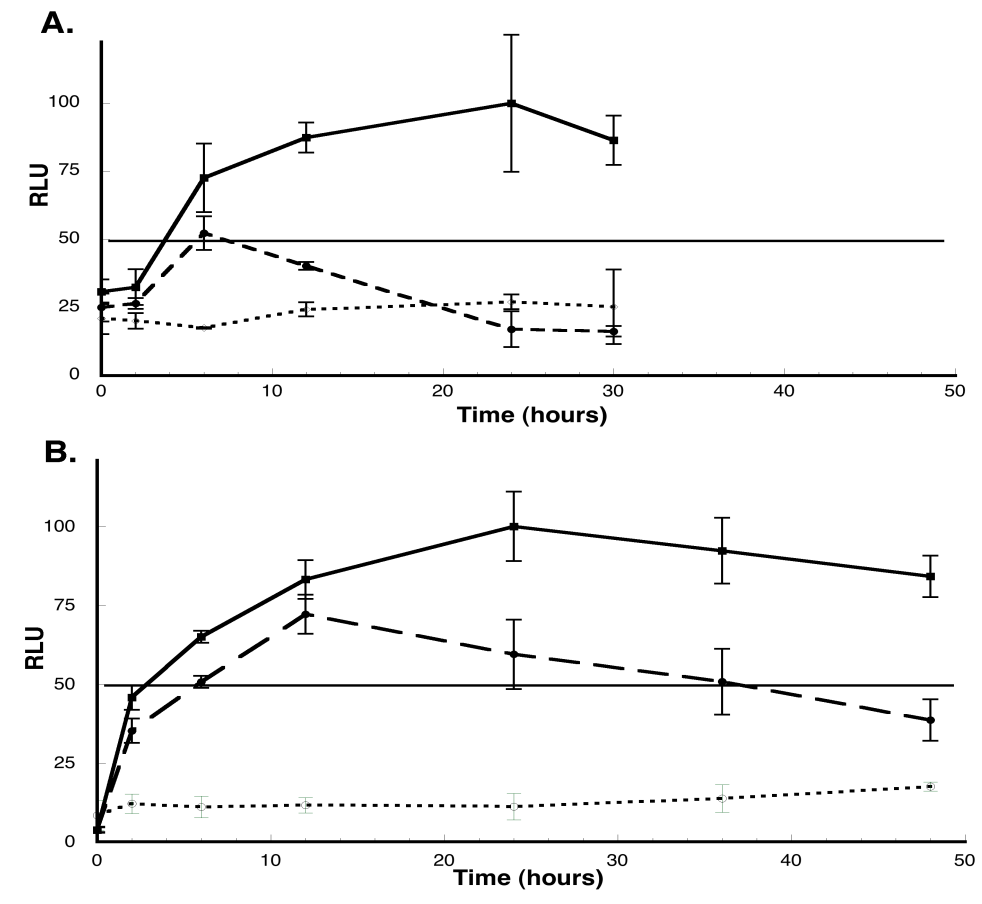

Figure 3.9: Time dependence of luciferase formation after a 90 second exposure. (A) Cells expressing RAR reporter gene with $800 \mathrm{nM}$ of $\mathbf{3}$. (B) Cells expressing the TR reporter gene with $500 \mathrm{nM}$ of 4 . Solid: ligand uncaged in media and cells; Dash: ligand uncaged in cells only after prewashing; Circle: not irradiated. 
The TR response shows approximately $80 \%$ maximum level of expression in 12 hours and then decreases. The transcription is sustained at $50 \%$ for over 36 hours (Figure 3.9B), whereas RAR only shows $50 \%$ activity for a few hours and quickly drops off. These studies show that different time-dependent transcription profiles can be obtained by different nuclear receptors even using the same cell line and reporter gene. Therefore, the TR receptor with caged ligand $\underline{4}$ can provide a unique tool for controlling sustained signal transduction.

Whereas the duration of reporter gene response depends on both the stability of the mRNA and the stability of the gene product in this case, the magnitude and duration of transactivation response is thought to be dependent upon the stability of the active transcription complex (Figure 3.10). By using the same reporter gene construct for both TR and RAR, this work shows unequivocally that the duration of transcription response can vary significantly depending on the properties of the receptor-ligand pair. The formation and stability of the ligand-receptor complex is more complicated than simply depending on the on-rate and off-rate of the ligand and can be influenced by the presence of co-repressors and co-activators as well as active ubiquitin-mediated proteolysis of the receptor. Thus it is likely that different behaviors may be observed in different cell types. 


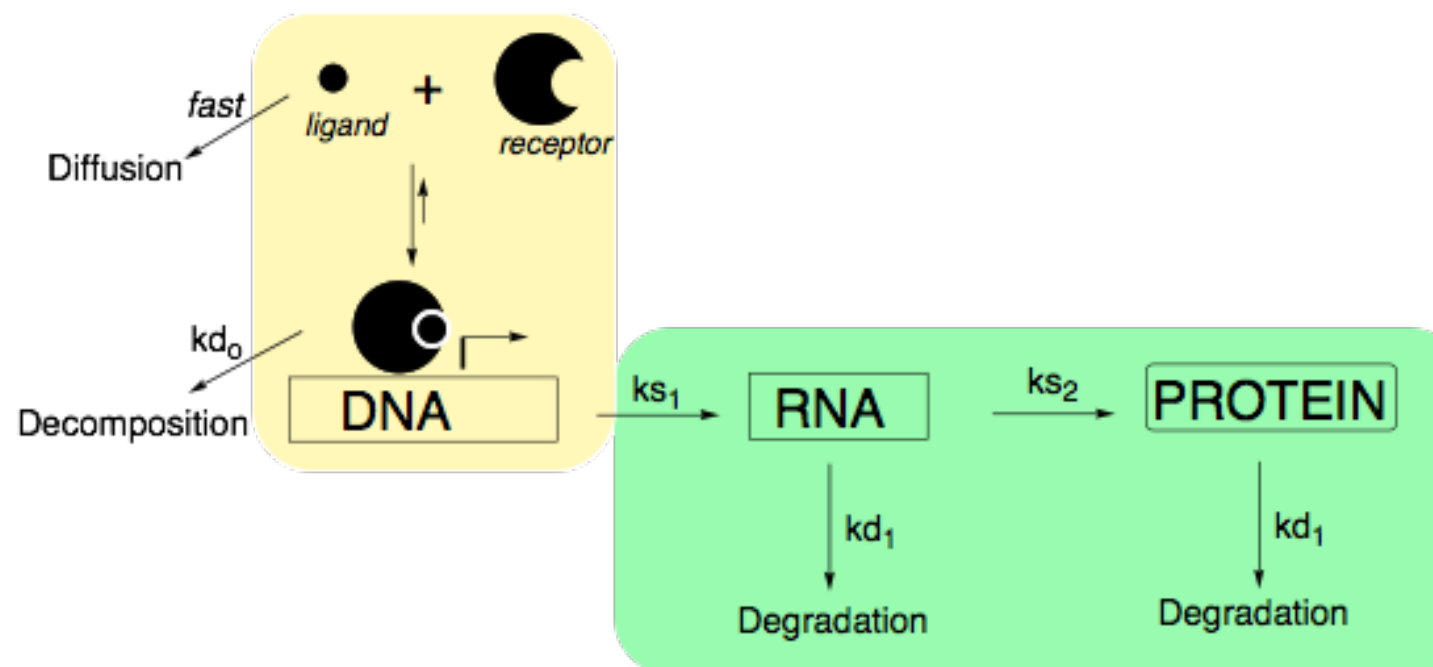

Figure 3.10: The formation of protein product is represented as an intermediate between transcription/translation and protein degradation. The duration of transactivation response is limited by the decomposition of the receptor-associated transcription complex.

Combined with our initial studies in chapter 2 which described the timedependent transcription profile for intracellular activation of the steroid receptor ER, light-activated transcription using the nuclear receptor TR and caged agonist $\underline{4}$ provide a sustained level of transcription response that has many properties necessary for performing gene patterning in tissues. The TR based system shows significant improvements over the initial ER based system developed in Chapter 2. The washin/wash-out characteristics of small molecule effectors allows one to manipulate and observe patterned cells without causing additional gene activation. Meanwhile the initial gene patterning is sustained for up to $36 \mathrm{~h}$. These studies laid the foundation for 
and defined the necessary parameters that would ultimately be used by others to perform gene patterning studies in cell and in tissues that are still be used to this day.

\subsection{Methods}

\subsubsection{Transient Transfection Assays}

HeLa cells were seeded at a density of 40,000 cells per well in six-well culture plates before transfection. The cells were grown in Dulbecco's Modified Eagle Medium, (DMEM) without phenol red supplemented with $10 \%$ fetal bovine serum and gentamycin. Three hours before transfection, the media was changed to DMEM containing $10 \%$ charcoal-resin stripped FBS. This was performed to deplete endogenous hormones from the media. The transfections were performed by using calcium phosphate. pSG5hRARg and pSG5hTRb were used as the receptor DNA, DR4-Luc+ as the promoter and pRLCMV as the control. Twenty hours after the transfection, the media was removed and replaced with media that contained the appropriate concentration of ligand. All manipulations involving the photocaged ligands were performed in the dark with the use of darkroom safelight. The cells were allowed to incubate in media containing the ligand for 12 hours prior to exposure. After exposure the cells were allowed to incubate for an additional 24 hours before harvesting by passive lysis. Cell extracts were immediately assayed using the Dual Luciferase Assay using a Dynex luminometer. Bioluminescence activity is reported in 
relative lights unit (RLU) determined as the ratio of the firefly luminescence divided by the luminescence of the renilla luciferase control. Each sample had three replicates.

\subsubsection{Cell Exposure Procedure}

Cells were irradiated from above using our apparatus design described earlier. The cell culture plates were exposed between 10 to 300 seconds through a 4 mm thick glass plate and the polystyrene culture plate lid which was used as a filter for the short wavelength UV.

\subsubsection{Intracellular De-protection by Prewashing}

To determine if the ligands were being deprotected inside the cells, HeLa cells were transiently transfected with the respective receptor, promoter, and control DNA plasmids. The cells were allowed to incubate for 12 hours in the presence of the active agonists or photocaged analogs. The cells were rapidly washed with PBS buffer followed by replacing with ligand-free media. The cells were immediately irradiated after the media changed. The cells were irradiated for 30 and 180 seconds to deprotect the photo-caged ligands. The cells were allowed to incubate for 0 to 48 hours before harvesting by passive lysis. 


\subsubsection{Evaluation of Compound Stability to Cell Lysates}

In order to determine if the ligands were being deprotected in the cells in the absence of light exposure. The photocaged ligands were preincubated in cell lysate and assayed for the activity. Solutions of the photocaged ligands in cell lysate were allowed to incubate for 36 hours at $37^{\circ} \mathrm{C}$.

\subsection{Synthesis}

Ethyl 4-[(E)-2[3-(1-adamantyl)-4-hydroxyphenyl]ethyl]-benzoate (ㅁ).

To a solution of $\underline{\mathbf{1}}(0.45 \mathrm{~g}, 1.2 \mathrm{mmol})$ in $5 \mathrm{~mL}$ of ethanol was slowly added $0.064 \mathrm{~mL}$ of concentrated sulfuric acid (98\%). The solution was refluxed for 12 hours, neutralized with sodium bicarbonate, and extracted with $2 \times 10 \mathrm{~m}$ ether. The combined organic extracts were dried over $\mathrm{MgSO}_{4}$, and evaporated in vacuo to give $0,416 \mathrm{~g}$ $(85.6 \%)$ of a yellow solid. ${ }^{1} \mathrm{H}$ NMR $\left(400 \mathrm{MHz}, \mathrm{CDCl}_{3}\right): \delta 1.38(\mathrm{t}, 3 \mathrm{H}), 1.78(\mathrm{~s}, 6 \mathrm{H})$, $2.12(\mathrm{~s}, 9 \mathrm{H}), 4.39(\mathrm{q}, 2 \mathrm{H}), 6.80(\mathrm{~d}, J=8 \mathrm{~Hz}, 1 \mathrm{H}), 6.93(\mathrm{~d}, J=16 \mathrm{~Hz}, 1 \mathrm{H}), 7.16(\mathrm{~d}, J=$ $16 \mathrm{~Hz}, 1 \mathrm{H}), 7.22(\mathrm{dd}, J=8,2 \mathrm{~Hz}, 1 \mathrm{H}), 7.34(\mathrm{~d}, J=2 \mathrm{~Hz}, 1 \mathrm{H}), 7.51(\mathrm{~d}, J=8 \mathrm{~Hz}, 2 \mathrm{H})$,

$8.01(\mathrm{~d}, J=8 \mathrm{~Hz}, 2 \mathrm{H}){ }^{13} \mathrm{C} \mathrm{NMR}\left(100 \mathrm{MHz}, \mathrm{CDCl}_{3}\right): \delta 166.50,164.95,159.15$ $142.34,138.75,131.51,129.94,128.65,125.91,125.41,125.37,124.99,111.87$, 55.10, 40.53, 37.86, 29.07, 14.37. MS (FAB) calcd for $\mathrm{C}_{27} \mathrm{H}_{30} \mathrm{O}_{3}\left(\mathrm{MH}^{+}\right)$402.2165, found: 402.1147 . 
Ethyl 4-\{(E)-2-[3-(1-adamantyl)-4-[(nitroveratryl)oxy]ethenyl]-benzoate (ㅁ) .

To a suspension of $\underline{\mathbf{5}}(0.100 \mathrm{~g}, 0.25 \mathrm{mmol})$ and $\mathrm{K}_{2} \mathrm{CO}_{3}(0.069 \mathrm{~g}, 0.50 \mathrm{mmol})$ in 1 $\mathrm{mL}$ of dry DMF was added dropwise a solution of $(0.069 \mathrm{~g}, 0.25 \mathrm{mmol})$ nitroveratryl bromide in $1 \mathrm{~mL}$ of dry DMF. The resulting solution was allowed to stir for 12 hours and extracted with $2 \times 10 \mathrm{~mL}$ ether. The combined organic extracts were dried over $\mathrm{MgSO}_{4}$, evaporated in vacuo, and purified by flash chromatography hexanes/ethyl acetate (50:50) to afford $0.125 \mathrm{~g}(83.1 \%)$ of a yellow solid. ${ }^{1} \mathrm{H}$ NMR $(400 \mathrm{MHz}$, $\left.\mathrm{CDCl}_{3}\right): \delta 1.40(\mathrm{t}, 3 \mathrm{H}), 1.78(\mathrm{~s}, 6 \mathrm{H}), 2.11(\mathrm{~s}, 9 \mathrm{H}), 3.87(\mathrm{~s}, 3 \mathrm{H}), 3.99(\mathrm{~s}, 3 \mathrm{H}), 4.39(\mathrm{q}$, 2H), $5.63(\mathrm{~s}, 2 \mathrm{H}), 6.81(\mathrm{~d}, J=8.5 \mathrm{~Hz}, 1 \mathrm{H}), 6.99(\mathrm{~d}, J=16.3 \mathrm{~Hz}, 1 \mathrm{H}), 7.18(\mathrm{~d}, J=16$ $\mathrm{Hz}, 1 \mathrm{H}), 7.26(\mathrm{~s}, 1 \mathrm{H}), 7.28(\mathrm{dd}, J=8,2 \mathrm{~Hz}, 1 \mathrm{H}), 7.46(\mathrm{~d}, J=2 \mathrm{~Hz}, 1 \mathrm{H}), 7.54(\mathrm{~d}, J=$ $8.4 \mathrm{~Hz}, 2 \mathrm{H}), 7.80(\mathrm{~s}, 1 \mathrm{H}), 8.01(\mathrm{~d}, J=8.3 \mathrm{~Hz}, 2 \mathrm{H}){ }^{13} \mathrm{C} \mathrm{NMR}\left(100 \mathrm{MHz}, \mathrm{CDCl}_{3}\right): \delta$ 169.10, 166.50, 164.95, 162.3, 159.15, 147.7, 142.34, 141.1, 138.75, 131.51, 129.94, $128.65,125.91,125.41,125.37,124.99,111.87,109.40,107.9,81.9,55.10,40.53$, 37.86, 29.07, 14.37. MS (FAB) calcd for $\mathrm{C}_{36} \mathrm{H}_{40} \mathrm{O}_{8} \mathrm{~N}\left(\mathrm{MH}^{+}\right)$614.2729, found: 614.0856.

[(E)-2[3-(-1-adamantyl)-4-[(nitroveratryl)oxy]phenyl]ethenyl]-benzoic acid (3).

A solution of $\underline{\mathbf{6}}(0.100 \mathrm{~g}, 0.25 \mathrm{mmol})$ and $0.069 \mathrm{~g}(0.12 \mathrm{mmol})$ of $\mathrm{LiOH}$ in 2 $\mathrm{mL}$ of $\mathrm{THF} / \mathrm{H}_{2} \mathrm{O}(4: 1)$ was allowed to react for 6 hours at ambient temperature. The reaction mixture was extracted with $3 \times 10 \mathrm{~mL}$ ether. The combined organic extracts were dried over $\mathrm{MgSO}_{4}$, evaporated in vacuo, and purified by flash chromatography hexanes/ethyl acetate (40:60) to give $0.075 \mathrm{~g}(75.1 \%)$ of a yellow solid. 
${ }^{1} \mathrm{H}$ NMR (400 MHz, CDCl 3 ): $\delta 1.78$ (s, 6H), 2.11 (s, 9H), 3.87 (s, 3H), 3.99 (s, 3H), $5.63(\mathrm{~s}, 2 \mathrm{H}), 6.81$ (d, $J=8.5 \mathrm{~Hz}, 2 \mathrm{H}), 6.99(\mathrm{~d}, J=16.3 \mathrm{~Hz}, 1 \mathrm{H}), 7.18$ (d, $J=16.3 \mathrm{~Hz}$, 1H), $7.26(\mathrm{~s}, 1 \mathrm{H}), 7.28(\mathrm{dd}, J=8,2 \mathrm{~Hz}, 1 \mathrm{H}), 7.46(\mathrm{~d}, J=2 \mathrm{~Hz}, 1 \mathrm{H}), 7.54(\mathrm{~d}, J=8.4$ $\mathrm{Hz}, 2 \mathrm{H}), 7.80(\mathrm{~s}, 1 \mathrm{H}), 8.01(\mathrm{~d}, J=8.3 \mathrm{~Hz}, 2 \mathrm{H}){ }^{13} \mathrm{C} \mathrm{NMR}\left(100 \mathrm{MHz}, \mathrm{CDCl}_{3}\right)$ :

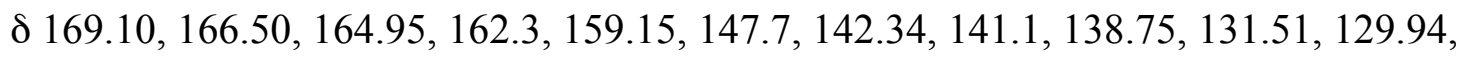
$128.65,125.91,125.41,125.37,124.99,111.87,109.40,107.9,81.9,40.53,37.86$, 29.07. MS (FAB) calcd for $\mathrm{C}_{34} \mathrm{H}_{35} \mathrm{O}_{8} \mathrm{~N}\left(\mathrm{MH}^{+}\right)$585.6562, found: 585.2453 . 


\section{REFERENCES}

1. Gossen, M.; Bonin, A.; Bujard, H., Control of gene activity in higher eukaryotic cells by prokaryotic regulatory elements. Trends in Biochemical Sciences 1993, 18 (12), 471-475.

2. Allgood, V.; Eastman, E.; Bristol, J., Novel gene switches for the regulation of gene expression. Annual Reports in Medicinal Chemistry, Vol 32 1997, 32, 231-239.

3. Allgood, V.; Eastman, E., Chimeric receptors as gene switches. Current Opinion in Biotechnology 1997, 8 (4), 474-479.

4. Damke, H.; Gossen, M.; Freundlieb, S.; Bujard, H.; Schmid, S., Tightly regulated and inducible expression of dominant interfering dynamin mutant in stably transformed Hela-cells. Small Gtpases and Their Regulators, Pt C 1995, 257, 209-220.

5. No, D.; Yao, T.; Evans, R., Ecdysone-inducible gene expression in mammalian cells and transgenic mice. Proceedings of the National Academy of Sciences of the United States of America 1996, 93 (8), 3346-3351.

6. Werstuck, G.; Green, M., Controlling gene expression in living cells through small molecule-RNA interactions. Science 1998, 282 (5387), 296-298.

7. Spencer, D.; Wandless, T.; Schreiber, S.; Crabtree, G., Controlling signaltransduction with synthetic ligands. Science 1993, 262 (5136), 1019-1024.

8. Panman, L.; te Welscher, P.; Soete, G.; Michos, O.; Zeller, R.; Zuniga, A., Spatial and temporal aspects of SHH signaling during limb patterning. Developmental Biology 2002, 247 (2), 475-475.

9. Sanz-Ezquerro, J.; Tickle, C., Digital development and morphogenesis. Journal of Anatomy 2003, 202 (1), 51-58.

10. Zernicka-Goetz, M., Patterning of the embryo: the first spatial decisions in the life of a mouse. Development 2002, 129 (4), 815-829.

11. Curley, K.; Lawrence, D., Photoactivation of a signal transduction pathway in living cells. Journal of the American Chemical Society 1998, 120 (33), 8573-8574. 
12. Wood, J.; Koszelak, M.; Liu, J.; Lawrence, D., A caged protein kinase inhibitor. Journal of the American Chemical Society 1998, 120 (28), 7145-7146.

13. Curley, K.; Lawrence, D., Caged regulators of signaling pathways. Pharmacology \& Therapeutics 1999, 82 (2-3), 347-354.

14. Curley, K.; Lawrence, D., Light-activated proteins. Current Opinion in Chemical Biology 1999, 3 (1), 84-88.

15. Costet, P.; Lalanne, F.; Gerbod-Giannone, M.; Molina, J.; Fu, X.; Lund, E.; Gudas, L.; Tall, A., Retinoic acid receptor-mediated induction of ABCA1 in macrophages. Molecular and Cellular Biology 2003, 23 (21), 7756-7766.

16. Ishii, H.; Tezuka, T.; Ishikawa, H.; Takada, K.; Oida, K.; Horie, S., Oxidized phospholipids in oxidized low-density lipoprotein down-regulate thrombomodulin transcription in vascular endothelial cells through a decrease in the binding of RAR beta-RXR alpha- heterodimers and $\mathrm{Sp} 1$ and $\mathrm{Sp} 3$ to their binding sequences in the TM promoter. Blood 2003, 101 (12), 4765-4774.

17. Ijpenberg, A.; Jeannin, E.; Wahli, W.; Desvergne, B., Polarity and specific sequence requirements of peroxisome proliferator-activated receptor (PPAR) retinoid $\mathrm{X}$ receptor heterodimer binding to DNA - A functional analysis of the malic enzyme gene PPAR response element. Journal of Biological Chemistry 1997, 272 (32), 2010820117.

18. Sanguedolce, M.; Leblanc, B.; Betz, J.; Stunnenberg, H., The promoter context is a decisive factor in establishing selective responsiveness to nuclear class II receptors. Embo Journal 1997, 16 (10), 2861-2873.

19. Charpentier, B.; Bernardon, J.; Eustache, J.; Millois, C.; Martin, B.; Michel, S.; Shroot, B., Synthesis, structure-affinity relationships, and biological activities of ligands binding to retinoic acid receptor subtypes. Journal of Medicinal Chemistry 1995, 38 (26), 4993-5006.

20. Chiellini, G.; Apriletti, J.; Yoshihara, H.; Baxter, J.; Ribeiro, R.; Scanlan, T., A high-affinity subtype-selective agonist ligand for the thyroid hormone receptor. Chemistry \& Biology 1998, 5 (6), 299-306.

21. Jeyakumar, M.; Webb, P.; Baxter, J.; Scanlan, T.; Katzenellenbogen, J., Quantification of ligand-regulated nuclear receptor corepressor and coactivator binding, key interactions determining ligand potency and efficacy for the thyroid hormone receptor. Biochemistry 2008, 47 (28), 7465-7476. 


\section{EPILOGUE}

New methods to create and control spatial and temporal patterns of expressed gene products may serve as a powerful tool to elucidate the function of many genes, that elicit their function only through unique spatial and temporal patterns of expression. Therefore, light-activated gene expression using caged agonists of transcription factors provides several unique advantages over prior photo-patterning methods used in multicellular systems.

Prior to this work, most methods relied on photocaged biopolymers: cagedprotein, caged-DNA or caged-RNA. Large biopolymers are difficult to introduce into multicellular organisms and once introduced the cells remain indefinitely light sensitive. Caged nuclear hormone receptor agonists are diffuse freely and can be added to and removed from cells at any time. One clear limitation is that uncaged ligand can diffuse away from the site of irradiation thus limiting resolution and the duration of response.

The tight binding of hormones to NHRs and kinetics of transcription complex assembly and disassembly mean that the duration of transcription response is not dependent on the rate of diffusion and is different for different receptor types. Under identical conditions RAR shows a relatively short duration response whereas a thyroid hormone receptor agonist provided 36 hours of reporter gene response to a single irradiation event. When comparing these two systems, the duration of transcription 
response is not controlled by the rate of diffusion of the ligand out of the cell but the rate of transcription loss by the inactivation of the active transcription complex.

Following these initial pioneering studies, Koh group graduate student Kristian Link used the photo caged ER antagonist Tamoxifen-aziridine (Taz) to control the conditional recombinase $\mathrm{CreER}^{\mathrm{T}}$ to affect genetic recombination in cultured cells. Taz could apparently extend the lifetime of the ER-ligand complex by forming a covalent complex with ER that was less prone to proteasomal degradation. Significantly, sitespecific recombination can permanently turn-off or turn-on a gene of interest.

Others have developed caged ligands for bacterial transcription factors such as the Tet-repressor or Tet-On system for use in both bacteria and mammalian cells. Light-activated methods for controlling gene expression in bacteria has some limited applications but spatial patterning is less relevant in unicellular organisms. Activation of caged agonists of NHRs will also activate endogenous hormone responsive genes. Exogenous receptors or xenobiotic ligands can be used to impart selectivity for only the receptor or gene of interest. The exogenous recptors such as the ecdysone receptor or the tetracycline repressor Tet- $\mathrm{R}$ and engineered ligand activated transcription factor, Tet-ON, have also been used to selectively control only the gene of interest without affecting endogenous genes. Koh group members Dr. John Biggins and Atsushi Hashimoto created a photo-caged form of a bioorthogonal receptor-ligand pair created from the vitamin D receptor (VDR). The compound NvA11 was evaluated for its ability to control the modified receptor VDR(R274L) which otherwise does not respond to endogenous vitamin $\mathrm{D}_{3}{ }^{7}$. 
Koh group graduate student Daniel Sauers and Dr. Murali Temburni attempted to use the TR based system to pattern cell monolayers but ultimately found that the background expression levels were too high. They use caged doxycycline (Nv-Dox) in the transactivator/repressor system RetroTET-ART to pattern the expression of ephrin A5 on cell monolayers to determine resolution limits of light-directed gene patterning with caged small moleucles to be on the order of 200 microns. Significantly, they used the transient light sensitivity of diffusible effectors to show that patterned ephrin A5 could direct and segregate co-cultured cells through either attractive or repulsive signals patterned by light. This and related studies demonstrated both the limitations and utilities of the pioneering methods described in Chapters 2 and 3.

\begin{tabular}{|c|c|c|l|}
\hline Year & Receptor & & Note \\
\hline $200 *^{* 1}$ & ER & & $\begin{array}{l}\text { UD: First light-activated } \\
\text { system based on a small } \\
\text { molecule effector. }\end{array}$ \\
\hline $2002^{2}$ & EcR & $\begin{array}{l}\text { First, example of spatial } \\
\text { control in a multicellular } \\
\text { system. }\end{array}$ \\
\hline $200 *^{3}$ & TR & $\begin{array}{l}\text { Nuclear receptor activation } \\
\text { with sustained transcription } \\
\text { response. }\end{array}$ & $\begin{array}{l}\text { Different receptors can show } \\
\text { significantly different } \\
\text { responses. }\end{array}$ \\
\hline $200 *^{3}$ & RAR & &
\end{tabular}




\begin{tabular}{|l|l|l|}
\hline $2004^{4}$ & ER & $\begin{array}{l}\text { First example of dual light } \\
\text { activated transcription and } \\
\text { repression of genes dependent } \\
\text { on response element. }\end{array}$ \\
\hline $2005^{5}$ & Cre-ER & $\begin{array}{l}\text { Covalent binding ligand } \\
\text { enhances lifetime of receptor- } \\
\text { ligand complex allowing for } \\
\text { permanent genomic } \\
\text { rearrangements }\end{array}$ \\
\hline $2006^{6}$ & Dox & $\begin{array}{l}\text { Light-activated transcription } \\
\text { using prokaryotic } \\
\text { transcription factor. }\end{array}$ \\
\hline $2007^{7}$
\end{tabular}

Table 4.1: Light-Activated Systems. *Work done by Cruz and et al. 


\section{REFERENCES}

1. Cruz, F.; Koh, J.; Link, K., Light-activated gene expression. Journal of the American Chemical Society 2000, 122 (36), 8777-8778.

2. Cambridge, S.; Geissler, D.; Keller, S.; Curten, B., A caged doxycycline analogue for photoactivated gene expression. Angewandte ChemieInternational Edition 2006, 45 (14), 2229-2231.

3. Link, K.; Cruz, F.; Ye, H.; O'Reilly, K.; Dowdell, S.; Koh, J., Photo-caged agonists of the nuclear receptors RAR gamma and TR beta provide unique time-dependent gene expression profiles for light-activated gene patterning. Bioorganic \& Medicinal Chemistry 2004, 12 (22), 5949-5959.

4. Link, K.; Shi, Y.; Koh, J., Light activated recombination. Journal of the American Chemical Society 2005, 127 (38), 13088-13089.

5. Sauers, D.; Temburni, M.; Biggins, J.; Ceo, L.; Galileo, D.; Koh, J., LightActivated Gene Expression Directs Segregation of Co-cultured Cells in Vitro. Acs Chemical Biology 2010, 5 (3), 313-320.

6. Lin, W.; Albanese, C.; Pestell, R.; Lawrence, D., Spatially discrete, lightdriven protein expression. Chemistry \& Biology 2002, 9 (12), 1347-1353.

7. Biggins, J.; Hashimoto, A.; Koh, J., Photocaged agonist for an analoguespecific form of the vitamin D receptor. Chembiochem 2007, 8 (7), 799803.

8. Shi, Y.; Koh, J., Light-activated transcription and repression by using photocaged SERMs. Chembiochem 2004, 5 (6), 788-796. 
Appendix $A$

\section{PERMISSIONS LETTERS}

Reprinted (adapted) with permission from Cruz, F.; Koh, J.; Link, K., Light-activated gene expression. Journal of the American Chemical Society 2000, 122 (36), 87778778. Copyright 2016 American Chemical Society.

Reprinted (adapted) with permission from Link, K.; Cruz, F.; Ye, H.; O'Reilly, K.; Dowdell, S.; Koh, J., Photo-caged agonists of the nuclear receptors RAR gamma and TR beta provide unique time-dependent gene expression profiles for lightactivated gene patterning. Bioorganic \& Medicinal Chemistry 2004, 12 (22), 5949-5959. Copyright 2016 Elsevier. 